\title{
Chapter Ten - Informing marine spatial planning decisions with environmental DNA
}

Bani, Alessia; De Brauwer, Maarten; Creer, Simon; Dumbrell, Alex J.; Limmon, Gino; Jompa, Jamaluddin; von der Heyden, Sophie ; Berger, Maria

\section{Advances in Ecological Research}

DOI:

10.1016/bs.aecr.2020.01.011

Published: 01/01/2020

Peer reviewed version

Cyswllt i'r cyhoeddiad / Link to publication

Dyfyniad o'r fersiwn a gyhoeddwyd / Citation for published version (APA):

Bani, A., De Brauwer, M., Creer, S., Dumbrell, A. J., Limmon, G., Jompa, J., von der Heyden, S., \& Berger, M. (2020). Chapter Ten - Informing marine spatial planning decisions with environmental DNA. Advances in Ecological Research, 62, 375-407.

https://doi.org/10.1016/bs.aecr.2020.01.011

\footnotetext{
Hawliau Cyffredinol / General rights

Copyright and moral rights for the publications made accessible in the public portal are retained by the authors and/or other copyright owners and it is a condition of accessing publications that users recognise and abide by the legal requirements associated with these rights. study or research.

- Users may download and print one copy of any publication from the public portal for the purpose of private

- You may not further distribute the material or use it for any profit-making activity or commercial gain

- You may freely distribute the URL identifying the publication in the public portal?
}

Take down policy

If you believe that this document breaches copyright please contact us providing details, and we will remove access to the work immediately and investigate your claim. 


\section{Informing marine spatial planning decisions with environmental DNA}

2 Alessia Bani ${ }^{1 *}$, Maarten De Brauwer ${ }^{2 *}$, Simon Creer $^{3}$, Alex J. Dumbrell ${ }^{1}$, Gino Limmon ${ }^{4}$, Jamaluddin 3 Jompa $^{5}$, Sophie von der Heyden ${ }^{6 \#}$ Maria Beger, ${ }^{2,7 \#}$

4 Author affiliations: * joint first author, \# joint last author

$5{ }^{1}$ School of Life Sciences, University of Essex, Wivenhoe Park, Colchester, Essex, CO4 3SQ, UK

$6 \quad{ }^{2}$ School of Biology, Faculty of Biological Sciences, University of Leeds, Leeds, LS2 9JT, UK

$7 \quad{ }^{3}$ School of Natural Sciences, Bangor University, Gwynedd, LL57 2UW, UK

$8{ }^{4}$ Maritime and Marine Science Center of Excellence, Pattimura University, J1. Dr. Leimena, Kampus

9 Poka, Ambon, Indonesia

$10{ }^{5}$ Graduate School, Hasanuddin University, Makassar, 90245, Indonesia

$11{ }^{6}$ Evolutionary Genomics Group, Department of Botany and Zoology, University of Stellenbosch, 12 Private Bag X1, Matieland, Stellenbosch, 7602, South Africa

$13 \quad{ }^{7}$ Centre for Biodiversity and Conservation Science, School of Biological Sciences, University of 14 Queensland, Brisbane, Queensland 4072, Australia

\section{Abstract:}

Marine management areas provide a key tool for national efforts towards sustainable development, reconciling socio-economic goals with those for biodiversity conservation. Decisions about where and when to establish spatial management areas in the oceans are currently hampered by the uncertainties of incomplete, or overly general, information about biodiversity. The analysis of environmental DNA (eDNA) provides a potentially powerful tool to overcome this lack of data in the future. Here we present directions to develop robust approaches to integrate eDNA and spatial planning processes, aiming to provide guidance to underpin tool development.

The potential of eDNA use in conservation is widely recognised, although direct applications almost exclusively focus on detection of invasive or threatened species and not spatial management decisions. The implementation of broader interaction between the fields of conservation science and eDNA analysis could create substantial benefits to biodiversity conservation and management. In particular, eDNA analysis can provide information on biodiversity over spatial-temporal scales that are currently prohibitive in spatial planning studies.

Here, we provide an overview of how eDNA is currently used in conservation practice, in addition to understanding its limitations and benefits within the context of spatial planning. With the goal to harness rapid technological developments in both molecular and conservation sciences, we provide a horizon scan of the future of eDNA analysis and its application to inform biodiversity conservation in a rapidly changing world.

Key words: eDNA, metabarcoding, tropical regions, biomonitoring, conservation, biodiversity, marine spatial planning 


\section{Introduction}

The management of biodiversity in tropical marine ecosystems relies to a large extent on spatial management actions, such as marine protected areas (Weeks et al., 2014, Tittensor et al., 2019), no-take zones (Russ et al., 2015), and fisheries management zones (McClanahan and Hicks, 2011). Spatial planning of these management actions plays a key role in implementing objective-driven transparent prioritisations (Wilson et al., 2007, Carvalho et al., 2017), often as part of national commitments to sustainable development goals and Convention of Biological Diversity (CBD) agreements. However, spatial planning for biodiversity conservation often fails to represent biodiversity patterns and associated bio-physical processes, because up-to-date spatial databases comprising the required data are often insufficient and lack spatial, temporal, and taxonomic coverage, particularly in resource-poor tropical developing countries. The representation of biodiversity in such spatial plans often relies on very broad proxies such as ecosystem extent (Green et al., 2009, Beger et al., 2010, Makino et al., 2015), habitat type (Grantham et al., 2013, Makino et al., 2015, Boon and Beger, 2016), or bioregions (Fernandes et al., 2005) and only rarely are there attempts to capture ecosystem condition (Vercammen et al., 2019). Given the global-scale declines observed in tropical marine ecosystems (Unsworth et al., 2016, Hughes et al., 2017), up-to-date and high-resolution biodiversity data play a pivotal role in implementing rapid management responses to the climate crisis. One potential solution to these challenges lies with the emergence of environmental DNA (eDNA) technologies, defined as "genetic material obtained directly from environmental samples (soil, sediment, water, etc.) without any obvious signs of biological source material" (Thomsen and Willerslev, 2015) (Box 1).

Spatial planning evaluates the trade-offs between protecting biodiversity features and ensuring socioeconomic sustainability in a transparent, quantitative, and repeatable manner (Margules and Pressey, 2000, Wilson et al., 2007, Carvalho et al., 2017, Kukkala and Moilanen, 2013). Such planning supports conservation management in efficiently reaching specific objectives by integrating multiple ecological and socio-economic variables to decide which areas should receive different conservation treatments. Importantly, effective spatial management decisions rely on carefully developed conservation objectives that are quantifiable and SMART (Specific Measurable Achievable Relevant Time-bound, 
(Maxwell et al., 2015). Key principles include connectivity (e.g. considering metapopulation dynamics and larval dispersal, (Makino et al., 2015), adequacy (e.g. protecting enough of each species/ habitat, and sites that support communities in good condition, (Magris et al., 2014), representation of local biodiversity, and efficiency (e.g. minimise impact on users and other costs, (Wilson et al., 2009). Therefore, uncertainties associated with the distribution of biodiversity features and supporting processes, i.e. failure to properly implement the first three principles, can lead to management decisions that are imprecise, select unsuitable areas, or create conflict between users (Game et al., 2014).

The logistical and cost restrictions associated with underwater surveys of biodiversity, even in shallow marine habitats, the lack of taxonomic expertise, and the lack of environmental predictors operating over appropriate spatiotemporal scales for species distribution modelling (e.g. contrasting $250 \mathrm{~m}^{2}$ survey areas vs $100 \mathrm{~km}^{2}$ analysis areas in common databases such as BioOracle, (Assis et al., 2018)), all currently severely hamper spatial management decisions. Whilst there has been some progress towards integrating genetic information into conservation prioritisation (Beger, Selkoe et al. 2014, Nielsen, Beger et al. 2017), this has yet to be extended to include eDNA data. eDNA could offer solutions to many of the challenges related to scale or taxonomic expertise in collecting data needed for spatial planning (Box 1). For example, eDNA could give wider geographical coverage and span broader taxonomic ranges of biodiversity than is currently possible to record (Deiner et al. 2017; Stat et al. 2017).

Arguably one of the most exciting recent tool developments in ecology is the increasing adaptation of the analysis of eDNA to answer ecosystem-level questions, moving onwards from its origins in environmental microbiology and ancient DNA studies (Clark et al., 2018). The vast potential of eDNA analysis has led to an explosion of novel, and previously unimaginable advances in the fields of ecology (e.g. Berry et al. (2019), Deiner et al. (2017a), De Vere et al. (2017)), palaeontology (e.g. Sønstebø et al. (2010), Willerslev et al. (2014)), and conservation (e.g. Weltz et al. (2017), Cilleros et al. (2019)). eDNA has a remarkably broad spatiotemporal application spanning a diversity of environmental matrices (soil, air, aquatic systems), resolution (from haplotypes that allow for the analysis of 
population level structure to entire communities) and time-frames (hours to millennia) (Ruppert et al., 2019). As such, eDNA is becoming a tool of choice for the monitoring of biodiversity, including in tropical marine environments (see for example Carvalho et al. (2019), DiBattista et al. (2019), Nichols and Marko (2019), Uthicke et al. (2018), Stat et al. (2017)) (Figure 1). However, ropical eDNA studies mostly come from a few regions such as the Red Sea (DiBattista et al., 2017, Carvalho et al., 2019) and Australia (e.g. Stat et al. 2017), leaving other regions such as South East Asia or South/Central America almost unexplored (Jerde et al., 2019). The systematic, large-scale use of eDNA and spatial planning could mean an incredible step forward in addressing this bias, where less developed, high biodiversity regions that are most threatened by human impacts are least understood and protected.

Much of the current eDNA literature has focused on tool development and addressing basic ecological questions. So far, few studies have interpreted how eDNA may be used to reveal spatiotemporal patterns and processes that could support spatial conservation decisions. In addition, inconsistencies in generating eDNA data and their analysis still limit the direct comparison and integration of different eDNA datasets that would allow for comparative analyses across larger spatial areas (McGee et al., 2019). Hence, streamlining potential future developments of eDNA tools and their application in ecology to underpin and support conservation decisions and processes presents a major opportunity in molecular and conservation sciences.

Here we assess how eDNA could be applied to spatial planning and suggest best-practice guidelines of eDNA in conservation management. Further, we propose the necessary research developments for eDNA to effectively contribute to the management and conservation of biodiversity that is applicable not only to tropical marine ecosystems, but also in terrestrial, freshwater and marine conservation efforts. We provide an overview of how eDNA is currently used in conservation practice, in addition to reviewing its limitations and benefits. We then complete a horizon scan of the future of eDNA as a tool to inform biodiversity conservation. 
eDNA data is often implied to be of high value for conservation initiatives (e.g. Stat et al. (2017), Ruppert et al. (2019)), but very few authors define how this would work in practice, beyond suggesting improved detection rates, or extend to the population level (Rees et al., 2014, Stat et al., 2017, Ruppert et al., 2019). eDNA has been used to detect invasive species such as bullfrogs, pythons, fish, and mussels (Ficetola et al., 2007, Hunter et al., 2015, Balasingham et al., 2017, Klymus et al., 2017, Holman et al., 2019) (Figure 1). Biomonitoring of cryptic or threatened species such as sawfishes, orang-utans, and crayfish that are challenging to monitor using conventional methods have benefitted from eDNA detection (Ikeda et al., 2016, Simpfendorfer et al., 2016, Ishige et al., 2017). Stewart et al. (2017) used eDNA to record the spatiotemporal distribution of the Yangtze finless porpoise (Neophocaena phocaenoides) to assess the effectiveness of protected areas in China. In addition, recent eDNA work has detected pathogens that might threaten rare populations of amphibians or crayfish (Kamoroff and Goldberg, 2017, Wu et al., 2018) (Figure 1).

eDNA studies in marine environments have included sediment, water column samples at different depths, plankton tows and stomach content. Different source materials harbour different communities and can provide complementary information (Holman et al., 2019). For example, sediments harbour more information about cryptic and benthic organisms (Pearman et al., 2018) but limited information on the fish assemblage that can be retrieved from water column samples at the same site (Koziol et al., 2019). Gut contents of predators can provide important information on their feeding behaviour or the distribution of prey (Correia et al., 2017). eDNA has also been successfully applied in monitoring the diet requirements of several species including sea lions (Neophoca cinerea) (Berry et al., 2017), or little penguins (Eudyptula minor) (Deagle et al., 2010), with studies of gut contents of parasites leading to a better understanding of the population structure of their hosts (Meekan et al., 2017).

In practice, however, few studies have used eDNA for species detection over large spatial or temporal scales in highly diverse environments such as the tropics (Cilleros et al., 2019, Stat et al., 2019). Longterm studies have tracked the effects of climate change on plankton biodiversity (Berry et al., 2019) and described shark diversity over large spatial scales (Boussarie et al., 2018). Temporal studies have 
tracked seasonality in coastal fish communities (Sigsgaard et al., 2017b) or in lake communities (Bista et al., 2017). The potential applications of eDNA analyses in threatened species management and conservation science might seem endless (Figure 1), but eDNA approaches have yet to be used for community analyses over large spatial scales or as part of land-based or marine spatial planning.

\section{Strategically integrating eDNA analysis and spatial planning}

eDNA data have the potential to revolutionise access to biodiversity information throughout the spatial planning process (Figure 2). Yet to truly understand this potential, we need to assess current and potential technological developments in both eDNA analysis and conservation science. An important component in applying eDNA to meeting many conservation objectives, is how to treat point-based eDNA data for mapping across continuous land- and sea-scapes. Even with the reduced expense that eDNA could bring, fine-scale sampling across large spatial areas is likely to still have high fiscal, labour, and computational costs for the foreseeable future. Therefore, innovative ways of mapping eDNA will be needed to meet conservation objectives. eDNA analyses result in Operational Taxonomic Units (OTUs) that serve as a proxy for species (see Glossary). The resulting sampling site $\times$ OTU matrix will still not cover the full spatial extent required for spatial planning analysis, therefore necessitating either interpolation between sampling sites (Beger et al., 2014, Nielsen et al., 2017), or predictive statistical modelling of OTU distributions (Figure 2). Such species distribution modelling is accomplished by relating occurrence, presence/absence, or abundance data to biophysical and socio-economic predictor variables (Elith and Leathwick, 2009, Guisan et al., 2013, Broennimann et al., 2012). Translation from eDNA data to abundance data is currently still problematic. While some studies have found positive correlations between the abundance of organisms and the quantity of eDNA molecules (Takahara et al., 2012), other studies have shown that eDNA quantities are dependent upon several factors including age, development stage, and environmental factors (Maruyama et al. (2014), Jo et al. (2019), Robson et al., 2016).

Given the potentially small spatial resolution of eDNA data and the uncertainty associated with OTU assignment, new modelling methods and small-scale biophysical parameter databases will be required. 
176 Thereafter, OTUs could be used as a proxy for species in spatial planning, and potentially be used in

177 three main ways when defining the spatial planning objectives (Figure 2): 1) setting conservation targets

178 for the amount of the distribution of each OTU to be protected; 2) generating broad multivariate community types for multiple taxa and setting conservation targets for these; and 3) setting (different) targets for OTUs with different distributional patterns, such as patchy vs consistently distributed. Information derived with eDNA analysis then can help evaluate current achievements of these objectives in a gap analysis (Figure 2, Vimal et al. (2011)). With repeat sampling, changes in OTU composition and relative abundance will be able to provide information on spatiotemporal community variation (Bista et al., 2017, Berry et al., 2019) and should expand our knowledge on intra and interspecific connectivity as well as population diversity especially with the developing of organelles sequencing (Adams et al., 2019). In addition, through concerted sequencing efforts, growing barcode and genomic reference databases should facilitate species-level identification of OTUs. This may provide further insight into the prediction of the distribution of species and the use of these data in spatial planning, specifically; whether the ecological or functional traits of species can be used to further refine species distribution models.

Finally, eDNA analysis can serve as a monitoring tool, where the achievement of objectives is assessed against resampled sites over a longer term (Figure 2), and where changes in management may be adopted when required as part of an adaptive management framework (Williams and Brown, 2016). The relative ease of collecting water samples for eDNA analysis from tropical marine environments will not only allow an increase in geographical scope, but also detect a higher number of species that could be monitored simultaneously, theoretically covering the entire ecosystems' diversity. A weak point of eDNA analysis is the lack of appropriately curated and extensively populated barcode reference databases, leading to incomplete taxonomic assignment, which may be particularly problematic for mega-diverse tropical marine ecosystems. Misclassification of OTUs or ASVs is linked also to the relative short length of the amplified fragments due the degree of degradation of eDNA molecules that could reduce the possibility to discriminate between closely related organisms (Porter and Hajibabaei, 2018b). 
Therefore, eDNA integration into spatial planning may require setting conservation objectives and implementing management actions for taxa (e.g. OTUs) at high taxonomic resolution (e.g. family level), whilst developing better databases (Table 2) (Porter and Hajibabaei, 2018b). Currently, spatial planning for known species applies mostly to cetaceans, reptiles and fishes, for which DNA reference databases are relatively well populated. Large global databases exist for mitochondrial (mtDNA) COI markers (Porter and Hajibabaei, 2018a), but most eDNA studies on freshwater and marine fish diversity utilise mtDNA 12S rRNA markers (Collins et al., 2019), for which reference databases are significantly smaller, as COI markers amplify phytoplankton too reducing the number of reads available for fish diversity (see Box 1 and Glossary for details on marker regions used in eDNA work). Focussing on generating reference databases across the tree of life, in particular to adequately represent the groups with key functional roles, is pivotal for the integration of eDNA results into spatial planning (Porter and Hajibabaei, 2018b). As more eDNA data are generated, similar efforts should be applied to expand the taxonomic resolution of all the main taxonomic or functional groups of organisms.

\section{Opportunities and challenges for eDNA analysis to inform spatial planning for conservation and}

\section{management}

Conservation organisations and government management agencies recognise the opportunities provided by eDNA. The unparalleled scope to detect Tree of Life assemblages of entire ecosystems with eDNA opens up multiple pathways to achieve more ambitious environmental management objectives. However, specifically within the context of spatial management, the benefits and limitations of eDNA need to be made clear, so that patterns of diversity recovered from eDNA can be interpreted appropriately. Currently, the lack of a consistent framework hampers the translation of eDNA data into spatial prioritisation plans, although eDNA data could be used to meet a wide variety of conservation objectives (Table 1). Major eDNA applications, from single species to whole community studies, include: 1) detection of low abundance species, 2) shortening of the time required to produce data, 3) cost reduction and 4) non-invasive or non-destructive sampling (Table 1). 
Increasingly, it is clear that not all species can be protected or saved from extinction in the face of ubiquitous anthropogenic impacts and limited conservation funds (Bottrill, et al. 2009, Beyer et al. 2018). Instead, environmental management needs to focus on maintaining functional integrity (D'agata et al., 2016). eDNA research may provide new opportunities to define ecosystem functionality (Cordier et al., 2017), and thus to develop approaches to protect these functions in a more targeted way (Sutherland et al., 2009, Sutherland et al., 2018). Rather than measuring a small subset of species (e.g. large predators, benthic cover), eDNA sampling can detect a large proportion of micro- and macrobiota within each replicate and test how OTU interactions change between samples to ultimately discover which taxa really drive ecosystem functions (Makiola et al., 2020). For example, eDNA could identify key generalist taxa that use a wide array of environments under varying impacts, and such species could be highly resilient species of value to conservation and restoration management actions. A better understanding of how species respond to varying impacts will allow managers to detect warning signs of changing ecosystems and adapt the spatial management in response.

The potential of eDNA to target the full species assemblage, analytical methods such as ecological network analysis are likely to gain importance (Table 1) (Evans et al., 2016). Network analyses can be of use in highlighting the sensitive groups that should be targeted in management or biomonitoring (Derocles et al., 2018). Co-occurrence network analysis could reveal the way in which conservation actions (or lack thereof) affect the biodiversity of entire ecosystems (Tulloch et al., 2018). Networks could also shed light on hitherto unknown mechanisms; rare species might be influenced by other taxa that are overlooked in many of the presently used survey methods. Trophic functioning of protected versus unprotected areas could be examined in new ways as eDNA offers the potential to accurately quantify producers or invertebrates at the base of the food chain as easily as the large fishes, which currently receive the bulk of research attention (Mora et al., 2011, Cinner et al., 2016, Cinner et al., 2018, Edgar et al., 2014, Martin et al., 2017). Stomach content analysis using eDNA has also been shown to be more accurate than visual analysis and can provide much needed data on trophic interactions (Jo et al., 2016). The higher taxonomic resolution that can be achieved using eDNA 
compared to conventional methods can further open up the way for far more specific spatial planning than is currently possible (Table 1).

Representing and maintaining genetic connectivity between different populations can form an important conservation objective in spatial planning (Carvalho et al., 2017). Such analyses of population genetics will increasingly benefit from eDNA data collection and advances in sequencing technology as multiple individuals (Sigsgaard et al., 2017a) and/or multiple taxa haplotypes (see Glossary) (Adams et al., 2019) can be studied at the same time. Inferring information on population genetics will become easier in the nearer future with expected cost reductions in organelle sequencing (full mitochondria or nuclear markers, see Deiner et al. (2017b)) and more comprehensive reference databases. Such advances are fundamental for monitoring and will provide information to spatial planners and managers to act rapidly and to establish best practices in ecosystem management and biodiversity conservation (Boehm et al., 2017)

\section{Guidelines: The practicalities of spatial planning with eDNA}

As with any other method, the key to obtaining accurate data relevant to conservation objectives is a well thought out experimental design and appropriate sampling method(s). While questions about the spatial coverage of eDNA are not yet fully resolved, enough is known to guide sampling design. The range at which the signature of eDNA can be detected varies from $50 \mathrm{~m}$ to several kilometres depending on the environment and conditions, which should be reflected in the aims and design of a study (e.g. Deiner and Altermatt (2014), Jeunen et al. (2019)). In the marine environment, eDNA can discriminate between different marine habitats, even at small spatial scales (Jeunen et al., 2019). In rivers, however, eDNA can potentially travel much further, up to $12 \mathrm{~km}$, depending on river flow rates and DNA degradation time (Deiner and Altermatt, 2014, Jane et al., 2015, Pont et al., 2018). Therefore, eDNA sampling design for spatial planning depends on conservation objectives and planning area. For example, if sampling effort aims to provide information on specific habitats, it is essential to get as close as possible to the source of the eDNA which best describes that habitat. If the goal is, however, to sample a large catchment or conduct initial, general biodiversity surveys, downstream sampling could be more advisable. Moreover, the number of samples to collect (i.e. replication) needs careful 
consideration under both aforementioned scenarios. Based on previous studies, more replicates with smaller volumes are preferable to a larger volume with less replication (Shaw et al., 2017, Dickie et al., 2018), and high replication ( $\mathrm{n}>>3$ ) is necessary to increase the detection rates of rarer taxa (Mächler et al., 2018, Rees et al., 2014).

While the relatively rapid degeneration of DNA makes eDNA sampling an ideal method to obtain estimates of recent diversity in a given area, this in turn brings uncertainties to designing eDNA protocols for spatial planning. Sampling might have to be repeated at multiple times throughout the year or target particular seasons (e.g. spawning events, migrations, monsoon vs dry season, etc.) depending on the goal of the sampling program (De Souza et al., 2016) and conservation objectives and spatial planning time frames. Thus, a thorough ecological understanding of the study system remains essential when designing monitoring plans (see for example Bylemans et al. (2018b)). This extends to the choice of source material. eDNA in sediments can provide precise information on different taxonomic levels, but data are less precise for obtaining information over short temporal scales. In addition, samples taken from sediments and the water column can harbour different eDNA signals (Holman et al., 2019), potentially as these capture biodiversity over longer and shorter temporal scales respectively. Conversely, sampling water could be a good solution for representing relative short time frames for a wide range of species (Collins et al., 2018).

A crucial aspect to effective tropical marine resource management is also integrating uncertainties and habitat status into spatial planning (Vercammen et al 2019), particularly for occupancy uncertainty of species or habitats. eDNA studies should therefore aim to provide such information to be relevant to conservation management. Quantifying chances of false negatives or false positives is currently not common practice in eDNA studies (but see Hunter et al. (2015)); future inclusion of these metrics would greatly benefit spatial planning. The primary risks of false positives are through contamination during sampling or extraction stages, or by wrongly assigning OTUs to a certain taxonomic species. It is essential that care is taken to avoid contamination where possible (for example, by using closed filters to capture eDNA), particularly in challenging fieldwork conditions or when engaging citizen scientists (Biggs et al., 2015, Julian et al., 2019). Increased DNA degradation rates under different conditions 
could increase chances of false negatives and have unintended consequences on conservation measures, such as removal of protective measures (Chadès et al., 2008).

312 Finally, current eDNA methods might not be suitable for all organisms of interest (e.g. Walker et al. 313 (2017)), or existing primer sets might not be able to detect the presence of phylogenetically distinct taxa such as Syngnathidae (Nester et al. in review). A combination of multiple primers (e.g. a "universal" $18 \mathrm{~S}$ primer set, combined with one or more targeted primers) could therefore result in more robust data on community composition and increased detection of rare species (Deiner et al. 2017a, Berry et al., 2019) without incurring prohibitive additional costs. Technological advances such as metagenomic or whole organelle sequencing will continue to improve eDNA methodology, (Porter and Hajibabaei, 2018b). Metagenomic sequencing has the potential to remove primer and PCR biases present in metabarcoding, however, its current use in eDNA analysis remains limited due to difficulties in assigning sequences to macro-organisms (Stat et al., 2017). It is therefore advised to test the methods proposed for use with novel combinations of rare or endangered species of interest to ensure efficiency.

\section{The future of eDNA in conservation planning science}

Technological innovations can provide a step-change in conservation science and practice in the face of escalating global biodiversity declines, but such technology needs to be developed in the context of well-defined conservation problems and applications (Iacona et al., 2019). Similarly, to enhance the relevance of new directions in eDNA approaches for spatial planning, it is necessary to carefully examine and standardise important features in the methodology that relate to spatial and taxonomic comprehensiveness (Table 2), ecological relevance, and SMART (Maxwell et al., 2015) implementation of spatial planning. Spatially comprehensive and real-time biodiversity data generation will be where eDNA analysis is likely to excel, with the potential to combine eDNA with autonomous sampling and machine learning to create global monitoring networks (Bohan et al., 2017). For example, Australia and New Zealand are considering using eDNA to support biological surveillance (Cristescu and Hebert, 2018). Such systems could link with app-based spatial planning (Daigle et al., 2018) or planning web-platforms (MARXAN, www.marxan.org, SEASKETCH https://www.seasketch.org/) that could apply pipelines to correctly apply eDNA data. Such technology supported spatial planning 
also has great potential in achieving community buy-in (Game et al., 2014). Automated eDNA

338 recording and monitoring systems could underpin new developments in dynamic ocean planning, where eDNA data could inform where, how and what is managed on short timeframes such as a week or biweekly (Hobday et al., 2011, Lewison et al., 2015, Dunn et al., 2016). Such improvements will lead to a reduced number of field scientists and bigger studies across larger spatial and temporal scales. Thus, quantifying and reporting the impacts on ecosystem and their relative services that are largely affected by climate changes, resource overexploitation or pollution at an unprecedented resolution.

As the use of eDNA in spatial planning becomes more common, scientists from disparate fields will require simple guidelines (Figure 3). As the use of eDNA in spatial planning would benefit from remote sampling and app-based application, sharing of data and especially of metadata would become fundamental. Nowadays only the raw sequences are requested to be stored in public database, accessible to everyone, while metadata that are equally important for large regional/global comparisons are often missing or incomplete. The use of Otlet-style data and sample sharing (https://otlet.io/) should become a good practice step in experimental setup with clear and well documented metadata upload systems (Figure 3).

\section{Conclusions}

The natural world is currently facing multiple interacting threats on an unprecedented scale that will considerably impact how human communities connect with natural resources. Adequate resource and conservation management of tropical marine ecosystems based on real-time, large-scale biodiversity is more important than ever, yet collecting and analysing such data remains challenging. It is beyond doubt that eDNA can and will play an increasingly large role in environmental research and it will likely increase the scope of future spatial planning. This review has outlined current and future possibilities on how to do this, as well as provide information on how to integrate eDNA in planning and how to avoid the most common mistakes. The rapidly developing applications of eDNA might seem daunting to non-experts, particularly since the technique is still very recent. While research gaps and methodological uncertainties exist, the method is ready to be tested for integration in spatial planning on a large scale. Effective marine spatial planning decisions depend on accurate and timely knowledge 
364 of the system to be managed. eDNA provides a step-change in how we think about the availability of 365 biodiversity data, and has the potential to completely redefine the spatio-temporal context of how 366 ecological systems are managed. 


\section{Molecular terminology}

370 Environmental DNA (eDNA): DNA directly extracted from environmental samples (soil, sediment, water, etc.) without any knowledge of the original organism.

PCR (Polymerase Chain Reaction): a molecular technique that allows the exponential amplification of a target fragment/region of DNA from a mixture of DNA fragments. The desired fragment to amplify is recognized from the other fragments in the mixture by specific primers (small single strand oligonucleotides) complementary to the desired sequence. The process is based on sequential cycles of heating and cooling at specific temperature. In the first step, the double strand DNA molecules are separated into single strands by high temperatures. In the second step, temperature is lowered, and primers bind to the complementary sequences of the targeted regions of DNA. In the third step, temperature is increased to the working optimum for the polymerase enzyme. The enzyme adds nucleotides to assemble the complementary sequence of the target DNA. During a PCR reaction, the three steps are repeated several times (between 25-30 cycles) and for each cycle the quantity of amplified DNA increases exponentially.

Quantitative PCR (qPCR): Quantitative PCR is a variant of PCR. The main difference between the two is that qPCR is able to quantify how many fragments of DNA are amplified during each step in the reaction, leading to quantitative data.

High Throughput Sequencing (HTS): a technique able to determine the nucleotide composition of millions of nucleic acid sequences. Different types of sequencing are now available and include Illumina, PacBio or NanoPore. Every sequencing method uses different strategies to generate the nucleic acid sequence, for example Illumina uses fluorescent nucleotides while NanoPore uses current change when DNA strand passes through a membrane protein. For more information please see van Dijk et al. (2018).

Metabarcoding: Taxonomic identification of millions of sequences in one experiment generated by PCR amplification on eDNA samples. This is possible using one of the HTS techniques. 
394 Metagenomics: Different from metabarcoding, metagenomics analyses do not require PCR amplification prior to sequencing. During the process, all DNA molecules are amplified together, which limits the error connected with PCR amplification.

Operational Taxonomic Unit (OTU): Sequences (reads) obtained from HTS are grouped together, to minimise the influence of PCR and sequencing error, based on threshold dissimilarity (usually $3 \%$ ). OTUs clusters are generated in programs such as VSEARCH or USEARCH. They are NOT species but an approximation to species. Clustering together multiple reads will inevitably reduce the information on nucleotide variations within that OTU.

Amplicon Sequence Variance (ASV): ASV does not include grouping reads based on dissimilarity but retains all the reads that are generated by HTS after a denoising step (removing of sequencing errors and chimera). Single nucleotide variation sequences are maintained in the dataset allowing the discrimination between different haplotypes within the same species. Programs that generate ASVs are DADA2 or Deblur. For a more detailed description of the difference between OTU and ASV see Callahan et al. (2017).

Haplotypes: a group of alleles that are inherited together from a single parent, for example mitochondrial haplotypes. Haplogroup are haplotypes that shared a common ancestor with a single nucleotide polymorphism mutation.

Cytochrome oxidase I (COI): Alternatively known as COX1 or CO1, it is a mitochondrial gene that encodes the main subunit of the cytochrome c complex. It is widely used to barcode eukaryotes. The reference database for this gene is known as BOLD database.

Barcode of Life Data (BOLD): Public database of COI gene sequenced across all the tree of Life. 12S rRNA: mitochondrial gene that is used for taxonomic assignment especially for fish.

\section{Conservation terminology}

Convention on Biological Diversity (CBD): International convention signed by 168 countries which aims to conserve biological diversity, promote sustainable use of biological diversity and ensure the fair and equitable sharing of the benefits arising out of the utilization of genetic resources. 
420 Data spatialisation: Transformation of site-specific environmental, biodiversity, and socio-economic 421 data into spatially-explicit map-based representations, typically achieved through distribution 422 modelling or interpolation.

423 Gap Analysis: Method used to identify problems or gaps that are likely to decrease the efficiency of 424 protected area managements. Gaps can range from exclusion of species or habitats, to missing 425 ecological processes, or problems in the management process itself.

426 Marine spatial planning: Framework to decide where to implement different management and 427 conservation actions by evaluating the trade-offs between protecting biodiversity features and ensuring 428 socio-economic sustainability in a transparent, quantitative, and repeatable manner.

429 Objectives: Quantitative specification of management goals for a certain ecosystem, habitat type, or 430 species. Objectives can be ecological, social, or economic, but should be detailed and quantifiable.

431 SMART (spatial planning): A conservation approach where objectives are Specific (clearly defined), 432 Measurable (specific on what will be measured and how), Achievable (realistic in light of existing 433 ecological and social conditions), Relevant (complementary to project goals), and Time-bound (clear 434 timeline). 
437 The analysis of microbial life using eDNA approaches has been commonplace for over 20 years, but their use to detect macro-organisms to investigate large scale ecological processes is more recent (Ficetola et al., 2007). Recently, eDNA methods have gained increasing attention as a possible alternative to survey rare or cryptic species, or to replace lethal or invasive survey techniques (Barnes and Turner, 2016, Jeunen et al., 2019). Environmental samples used in eDNA studies collect a mixture of DNA fragments originating from the various organisms present in that environment, regardless of whether these organisms are visible or morphologically identifiable in the source material. This pool of DNA is then extracted with commercial kits or other well-established protocols. It is then often necessary to amplify the amount of DNA present via Polymerase Chain Reaction technology (PCR, see Glossary), before identifying which taxa it originates from (although methods are increasingly moving away from amplification-based approaches). Whilst widely used for microorganisms, metagenomics (see Glossary) approaches are not routinely used in eDNA studies, with, to our knowledge, only one study that has attempted this method (Stat et al. (2017)). The main limitation for metagenomics is the very limited percentage of macro-organism DNA sequences that can be amplified (Stat et al. (2017)).

eDNA studies can be broadly classified into studies focussing on community composition or those that target specific organisms or even for population-level studies (Porter and Hajibabaei, 2018a). When targeting individual species, species-specific primers (employed during PCR) ensure that only the target species is amplified, with researchers utilising quantitative (or more recently digital) PCR (see Glossary) to provide estimates of biomass or cellular abundance (Porter and Hajibabaei, 2018a). This approach is common in the detection of invasive species, such as American bullfrogs (Rana catesbeiana) in France (Ficetola et al., 2007), the Asian Carp (Hypophthalmichthys sp.) in the USA (Bohmann et al., 2014), and Asian date mussels (Arcuatula senhousia) (Holman et al., 2019), alongside detecting threatened species; for example, the great crested newt (Triturus cristatus) in the UK, Endangered skates (Zearaja maugeana) in Australia, or nearly extinct freshwater fish (Misgurnus fossilis) of conservation concern in Denmark (Biggs et al., 2015, Sigsgaard et al., 2015, Weltz et al., 
services (see for example https://www.naturemetrics.co.uk/wildlife-services/gcn-edna/) particularly in

464 single-species management of invasive or threatened species.

465 For studies aiming to record all species present in a sample, High Throughput Sequencing (see Glossary

466 HTS) in the form of metabarcoding (see Glossary) is currently the most commonly applied approach.

467 Metabarcoding is the taxonomic identification of multiple species extracted from eDNA samples

468 (Deiner et al., 2017a). Metabarcoding primers employed during PCR aim to capture broad taxonomic 469 groups, for example, amplifying all the eukaryotes present, or targeting specific groups such as fish or crustaceans. These primers anneal to complementary sequence in the mixed pool of DNA fragments and only amplify copies of a selected genomic region that contains enough sequence information to facilitating species identification. These amplicons are then sequenced using one of the available HTS technologies (Illumina for example uses nucleotide labelled with different fluorochromes that are read by a laser while Nanopore using differences in membrane potential see van Dijk et al. (2018) for a review on HTS). The DNA sequence reads, generated via HTS, are then analysed to determine the species composition of the original sample. A series of bioinformatics tools are employed to generate ecologically-relevant data for biomonitoring and/or spatial planning. Typically, sequences are clustered in groups based on a predefined similarity threshold (OTUs; see Glossary) or left ungrouped to capture total genetic variation (ASVs; see Glossary). OTUs and/or ASVs are then matched to sequences of known taxonomic identity held in large databases, which then completes the identification of the species present.

The analysis of eDNA provides data that leverages the ability to monitor species composition and distribution in a quicker and often easier way than more traditional approaches (Bista et al., 2017, Bohan et al., 2017, Cristescu and Hebert, 2018). However, the probability of species detection via eDNA approaches, differs in many and often unknown ways; field and laboratory methods (McGee et al., 2019), sampling depths (Eilers et al., 2012, DiBattista et al., 2019) environmental substrate (Holman et al., 2019), and the chemical, physical, oceanographic and biological factors that influence eDNA degradation (Rees et al., 2014), all introduce potential biases. For example, water samples are more 
al., 2019). The distance eDNA travels from a source is highly variable, ranging from 50 meters (Jerde et al., 2016) to >200 meters (Jane et al., 2015, Pont et al., 2018). Heterogeneous sources of macrobial eDNA consist of different particles (mucus, skin, faeces etc.) that are transported, settled on the benthos, and resuspended in a complex and stochastic manner (Jerde et al., 2016, Shogren et al., 2017) and that may degrade differently according to their size Jo et al. (2017), Wei et al. (2018) but see the contrary in Bista et al. (2018), Bylemans et al. (2018a). Field sampling in tropical marine environments relies on many different strategies, including surface water (Cilleros et al., 2019), benthic water (Boussarie et al., 2018), and sediment samples (DiBattista et al., 2019), mirroring non-standardised sampling in the eDNA and metabarcoding fields (McGee et al., 2019). In addition, variation in laboratory procedures may influence the comparability of results across studies (McGee et al., 2019, Berry et al., 2019, Kelly et al., 2019) however the biggest variability is how the data are produced and analysed.

Illumina technology is currently most commonly used but other options are available and comparisons between different sequencing techniques can be challenging (Porter and Hajibabaei, 2018 b). One of the most debated steps in the bioinformatics workflow is sequence clustering. Researchers can cluster their sequences in OTU (see Glossary) based on a similarity threshold or treat them as ASV (see Glossary) without clustering (Deiner et al. (2017a)), Incorrect clustering can have strong effects on alpha diversity indices introducing overestimation or under estimation within the community (Pawlowski et al., 2018). Taxonomy can be assigned using a variety of programs that are based on different approaches including BLAST, MG-RAST or RDP which can lead to different outputs (Deiner et al. (2017a)). The use of different databases can similarly lead to different annotations and potential errors. Contrary to BOLD, NCBI database is not curated but recently has been demonstrated to be reliable for eDNA analysis (Leray et al., 2019) especially because error in taxonomic assignments are easier to correct as more information on biogeography are available for macro-organisms (Deiner et al. (2017a)).

514 We suggest the following reviews/articles for a better understanding of the above discussed possibilities and challenges that eDNA studies face. For general application of eDNA, we recommend Rees et al. 

on eDNA we strongly suggest Deiner et al. (2017a) and Kelly et al. (2019).

518

\section{References}

ADAMS, C. I., KNAPP, M., GEMMELL, N. J., JEUNEN, G.-J., BUNCE, M., LAMARE, M. D. \& TAYLOR, H. R. 2019. Beyond Biodiversity: Can Environmental DNA (eDNA) Cut It as a Population Genetics Tool? Genes, 10, 192.

ASSIS, J., TYBERGHEIN, L., BOSCH, S., VERBRUGGEN, H., SERRÃO, E. A. \& DE CLERCK, O. 2018. BioORACLE v2. 0: Extending marine data layers for bioclimatic modelling. Global Ecology and Biogeography, 27, 277-284.

BALASINGHAM, K. D., WALTER, R. P. \& HEATH, D. D. 2017. Residual eDNA detection sensitivity assessed by quantitative real-time PCR in a river ecosystem. Molecular ecology resources, 17, 523-532.

BARNES, M. A. \& TURNER, C. R. 2016. The ecology of environmental DNA and implications for conservation genetics. Conservation genetics, 17, 1-17.

BEGER, M., SELKOE, K. A., TREML, E., BARBER, P. H., VON DER HEYDEN, S., CRANDALL, E. D., TOONEN, R. J. \& RIGINOS, C. 2014. Evolving coral reef conservation with genetic information. Bulletin of Marine Science, 90, 159-185.

BEGER, M., SIMON, L., GAME, E., BALL, I., TREML, E., WATTS, M. \& POSSINGHAM, H. P. 2010. Incorporating functional ecological connectivity into spatial decision making for conservation. Conservation Letters, 3, 359-368.

BERRY, T. E., OSTERRIEDER, S. K., MURRAY, D. C., COGHLAN, M. L., RICHARDSON, A. J., GREALY, A. K., STAT, M., BEJDER, L. \& BUNCE, M. 2017. DNA metabarcoding for diet analysis and biodiversity: A case study using the endangered Australian sea lion (Neophoca cinerea). Ecology and Evolution, 7, 5435-5453.

BERRY, T. E., SAUNDERS, B. J., COGHLAN, M. L., STAT, M., JARMAN, S., RICHARDSON, A. J., DAVIES, C. H., BERRY, O., HARVEY, E. S. \& BUNCE, M. 2019. Marine environmental DNA biomonitoring reveals seasonal patterns in biodiversity and identifies ecosystem responses to anomalous climatic events. PLoS genetics, 15, e1007943.

BIGGS, J., EWALD, N., VALENTINI, A., GABORIAUD, C., DEJEAN, T., GRIFFITHS, R. A., FOSTER, J., WILKINSON, J. W., ARNELL, A. \& BROTHERTON, P. 2015. Using eDNA to develop a national citizen science-based monitoring programme for the great crested newt (Triturus cristatus). Biological Conservation, 183, 19-28.

BISTA, I., CARVALHO, G. R., TANG, M., WALSH, K., ZHOU, X., HAJIBABAEI, M., SHOKRALLA, S., SEYMOUR, M., BRADLEY, D. \& LIU, S. 2018. Performance of amplicon and shotgun sequencing for accurate biomass estimation in invertebrate community samples. Molecular ecology resources, 18, 1020-1034.

BISTA, I., CARVALHO, G. R., WALSH, K., SEYMOUR, M., HAJIBABAEI, M., LALLIAS, D., CHRISTMAS, M. \& CREER, S. 2017. Annual time-series analysis of aqueous eDNA reveals ecologically relevant dynamics of lake ecosystem biodiversity. Nature communications, 8, 14087.

BOEHM, A. B., ISMAIL, N. S., SASSOUBRE, L. M. \& ANDRUSZKIEWICZ, E. A. 2017. Oceans in peril: Grand challenges in applied water quality research for the 21st century. Environmental Engineering Science, 34, 3-15.

BOHAN, D. A., VACHER, C., TAMADDONI-NEZHAD, A., RAYBOULD, A., DUMBRELL, A. J. \& WOODWARD, G. 2017. Next-generation global biomonitoring: large-scale, automated reconstruction of ecological networks. Trends in Ecology \& Evolution, 32, 477-487. 
BOHMANN, K., EVANS, A., GILBERT, M. T. P., CARVALHO, G. R., CREER, S., KNAPP, M., DOUGLAS, W. Y. \& DE BRUYN, M. 2014. Environmental DNA for wildlife biology and biodiversity monitoring. Trends in ecology \& evolution, 29, 358-367.

BOON, P. Y. \& BEGER, M. 2016. The effect of contrasting threat mitigation objectives on spatial conservation priorities. Marine Policy, 68, 23-29.

BOUSSARIE, G., BAKKER, J., WANGENSTEEN, O. S., MARIANI, S., BONNIN, L., JUHEL, J.-B., KISZKA, J. J., KULBICKI, M., MANEL, S. \& ROBBINS, W. D. 2018. Environmental DNA illuminates the dark diversity of sharks. Science advances, 4, eaap9661.

BROENNIMANN, O., FITZPATRICK, M. C., PEARMAN, P. B., PETITPIERRE, B., PELLISSIER, L., YOCCOZ, N. G., THUILLER, W., FORTIN, M. J., RANDIN, C. \& ZIMMERMANN, N. E. 2012. Measuring ecological niche overlap from occurrence and spatial environmental data. Global ecology and biogeography, 21, 481-497.

BYLEMANS, J., FURLAN, E. M., GLEESON, D. M., HARDY, C. M. \& DUNCAN, R. P. 2018a. Does size matter? An experimental evaluation of the relative abundance and decay rates of aquatic environmental DNA. Environmental science \& technology, 52, 6408-6416.

BYLEMANS, J., GLEESON, D. M., LINTERMANS, M., HARDY, C. M., BEITZEL, M., GILLIGAN, D. M. \& FURLAN, E. M. 2018b. Monitoring riverine fish communities through eDNA metabarcoding: determining optimal sampling strategies along an altitudinal and biodiversity gradient. Metabarcoding and Metagenomics, 2, e30457.

CALLAHAN, B. J., MCMURDIE, P. J. \& HOLMES, S. P. 2017. Exact sequence variants should replace operational taxonomic units in marker-gene data analysis. The ISME journal, 11, 2639-2643.

CARVALHO, S., AYLAGAS, E., VILLALOBOS, R., KATTAN, Y., BERUMEN, M. \& PEARMAN, J. K. 2019. Beyond the visual: using metabarcoding to characterize the hidden reef cryptobiome. Proceedings of the Royal Society B, 286, 20182697.

CARVALHO, S. B., VELO-ANTÓN, G., TARROSO, P., PORTELA, A. P., BARATA, M., CARRANZA, S., MORITZ, C. \& POSSINGHAM, H. P. 2017. Spatial conservation prioritization of biodiversity spanning the evolutionary continuum. Nature Ecology \&Amp; Evolution, 1, 0151.

CHADÈS, I., MCDONALD-MADDEN, E., MCCARTHY, M. A., WINTLE, B., LINKIE, M. \& POSSINGHAM, H. P. 2008. When to stop managing or surveying cryptic threatened species. Proceedings of the National Academy of Sciences, 105, 13936-13940.

CILlEROS, K., VALENTINI, A., ALLARD, L., DEJEAN, T., ETIENNE, R., GRENOUILLET, G., IRIBAR, A., TABERLET, P., VIGOUROUX, R. \& BROSSE, S. 2019. Unlocking biodiversity and conservation studies in high-diversity environments using environmental DNA (eDNA): A test with Guianese freshwater fishes. Molecular ecology resources, 19, 27-46.

CINNER, J. E., HUCHERY, C., MACNEIL, M. A., GRAHAM, N. A. J., MCCLANAHAN, T. R., MAINA, J., MAIRE, E., KITTINGER, J. N., HICKS, C. C., MORA, C., ALLISON, E. H., D’AGATA, S., HOEY, A., FEARY, D. A., CROWDER, L., WILLIAMS, I. D., KULBICKI, M., VIGLIOLA, L., WANTIEZ, L., EDGAR, G., STUART-SMITH, R. D., SANDIN, S. A., GREEN, A. L., HARDT, M. J., BEGER, M., FRIEDLANDER, A., CAMPBELL, S. J., HOLMES, K. E., WILSON, S. K., BROKOVICH, E., BROOKS, A. J., CRUZ-MOTTA, J. J., BOOTH, D. J., CHABANET, P., GOUGH, C., TUPPER, M., FERSE, S. C. A., SUMAILA, U. R. \& MOUILLOT, D. 2016. Bright spots among the world's coral reefs. Nature, 535, 416-419.

CINNER, J. E., MAIRE, E., HUCHERY, C., MACNEIL, M. A., GRAHAM, N. A. J., MORA, C., MCCLANAHAN, T. R., BARNES, M. L., KITTINGER, J. N., HICKS, C. C., D'AGATA, S., HOEY, A., GURNEY, G. G., FEARY, D. A., WILLIAMS, I. D., KULBICKI, M., VIGLIOLA, L., WANTIEZ, L., EDGAR, G., STUARTSMITH, R. D., SANDIN, S. A., GREEN, A. L., HARDT, M. J., BEGER, M., FRIEDLANDER, A., WILSON, S. K., BROKOVICH, E., BROOKS, A. J., CRUZ-MOTTA, J. J., BOOTH, D. J., CHABANET, P., GOUGH, C., TUPPER, M., FERSE, S. C. A., SUMAILA, U. R., PARDEDE, S. \& MOUILLOT, D. 2018. The gravity of human impacts mediates coral reef conservation gains. Proceedings National Academy of Sciences, 115, E6116-E6125.

CLARK, D. R., FERGUSON, R. M., HARRIS, D. N., MATTHEWS NICHOLASS, K. J., PRENTICE, H. J., RANDALL, K. C., RANDELL, L., WARREN, S. L. \& DUMBRELL, A. J. 2018. Streams of data from drops of 
water: 21st century molecular microbial ecology. Wiley Interdisciplinary Reviews: Water, 5, e1280.

COLLINS, R. A., BAKKER, J., WANGENSTEEN, O. S., SOTO, A. Z., CORRIGAN, L., SIMS, D. W., GENNER, M. J. \& MARIANI, S. 2019. Non-specific amplification compromises environmental DNA metabarcoding with COI. Methods in Ecology and Evolution, 10, 1985-2001.

COLLINS, R. A., WANGENSTEEN, O. S., O'GORMAN, E. J., MARIANI, S., SIMS, D. W. \& GENNER, M. J. 2018. Persistence of environmental DNA in marine systems. Communications biology, 1, 185.

CORDIER, T., ESLING, P., LEJZEROWICZ, F., VISCO, J., OUADAHI, A., MARTINS, C., CEDHAGEN, T. \& PAWLOWSKI, J. 2017. Predicting the ecological quality status of marine environments from eDNA metabarcoding data using supervised machine learning. Environmental science \& technology, 51, 9118-9126.

CORREIA, E., GRANADEIRO, J. P., REgALLA, A., DIAS, E., ALMEIDA, A. \& CATRY, P. 2017. Predatory pelagic fishes of the Bijagós Archipelago (Guinea-Bissau) show high overlap in diets dominated by sardinella. African journal of marine science, 39, 389-396.

COSTELLO, M. J.; VANHOORNE, B. \& APPELTANS, W. 2015. Conservation of biodiversity through taxonomy, data publication, and collaborative infrastructures. Conservation Biology, 29.4, 1094-1099.

CRISTESCU, M. E. \& HEBERT, P. D. 2018. Uses and misuses of environmental DNA in biodiversity science and conservation. Annual Review of Ecology, Evolution, and Systematics, 49, 209-230.

D'AGATA, S., VIGLIOLA, L., GRAHAM, N. A., WANTIEZ, L., PARRAVICINI, V., VILLÉGER, S., MOU-THAM, G., FROLLA, P., FRIEDLANDER, A. M. \& KULBICKI, M. 2016. Unexpected high vulnerability of functions in wilderness areas: evidence from coral reef fishes. Proceedings of the Royal Society B: Biological Sciences, 283, 20160128.

DAIGLE, R. M., METAXAS, A., BALBAR, A., MCGOWAN, J., TREML, E. A., KUEMPEL, C. D., POSSINGHAM, H. P. \& BEGER, M. 2018. Operationalizing ecological connectivity in spatial conservation planning with Marxan Connect. bioRxiv, 315424.

DAVIS, A. J., WILLIAMS, K. E., SNOW, N. P., PEPIN, K. M. \& PIAGGIO, A. J. 2018. Accounting for observation processes across multiple levels of uncertainty improves inference of species distributions and guides adaptive sampling of environmental DNA. Ecology and evolution, 8, 10879-10892.

DE SOUZA, L. S., GODWIN, J. C., RENSHAW, M. A. \& LARSON, E. 2016. Environmental DNA (eDNA) detection probability is influenced by seasonal activity of organisms. PLoS One, 11, e0165273.

DE VERE, N., JONES, L. E., GILMORE, T., MOSCROP, J., LOWE, A., SMITH, D., HEGARTY, M. J., CREER, S. \& FORD, C. R. 2017. Using DNA metabarcoding to investigate honey bee foraging reveals limited flower use despite high floral availability. Scientific Reports, 7, 42838.

DEAGLE, B. E., CHIARADIA, A., MCINNES, J. \& JARMAN, S. N. 2010. Pyrosequencing faecal DNA to determine diet of little penguins: is what goes in what comes out? Conservation Genetics, 11, 2039-2048.

DEINER, K. \& ALTERMATT, F. 2014. Transport distance of invertebrate environmental DNA in a natural river. PloS one, 9, e88786.

DEINER, K., BIK, H. M., MÄCHLER, E., SEYMOUR, M., LACOURSIÈRE-ROUSSEL, A., ALTERMATT, F., CREER, S., BISTA, I., LODGE, D. M. \& DE VERE, N. 2017a. Environmental DNA metabarcoding: Transforming how we survey animal and plant communities. Molecular ecology, 26, 58725895.

DEINER, K., RENSHAW, M. A., LI, Y., OLDS, B. P., LODGE, D. M. \& PFRENDER, M. E. 2017b. Long-range PCR allows sequencing of mitochondrial genomes from environmental DNA. Methods in Ecology and Evolution, 8, 1888-1898.

DELMONT, T. O., QUINCE, C., SHAIBER, A., ESEN, Ö. C., LEE, S. T. M., RAPPÉ, M. S., MCLELLAN, S. L., LÜCKER, S. \& EREN, A. M. 2018. Nitrogen-fixing populations of Planctomycetes and Proteobacteria are abundant in surface ocean metagenomes. Nature Microbiology, 3, 804813. 
DEROCLES, S. A., BOHAN, D. A., DUMBRelL, A. J., KITSON, J. J., MASSOL, F., PAUVERT, C., PLANTEGENEST, M., VACHER, C. \& EVANS, D. M. 2018. Biomonitoring for the 21st century: integrating next-generation sequencing into ecological network analysis. Advances in Ecological Research. Elsevier.

DIBATTISTA, J. D., COKER, D. J., SINCLAIR-TAYLOR, T. H., STAT, M., BERUMEN, M. L. \& BUNCE, M. 2017. Assessing the utility of eDNA as a tool to survey reef-fish communities in the Red Sea. Coral Reefs, 36, 1245-1252.

DIBATTISTA, J. D., REIMER, J. D., STAT, M., MASUCCI, G. D., BIONDI, P., DE BRAUWER, M. \& BUNCE, M. 2019. Digging for DNA at depth: rapid universal metabarcoding surveys (RUMS) as a tool to detect coral reef biodiversity across a depth gradient. PeerJ, 7, e6379.

DICKIE, I. A., BOYER, S., BUCKLEY, H. L., DUNCAN, R. P., GARDNER, P. P., HOGG, I. D., HOLDAWAY, R. J., LEAR, G., MAKIOLA, A. \& MORALES, S. E. 2018. Towards robust and repeatable sampling methods in eDNA-based studies. Molecular ecology resources, 18, 940-952.

DJURHUUS, A., PORT, J., CLOSEK, C. J., YAMAHARA, K. M., ROMERO-MARACCINI, O., WALZ, K. R., GOLDSMITH, D. B., MICHISAKI, R., BREITBART, M. \& BOEHM, A. B. 2017. Evaluation of filtration and DNA extraction methods for environmental DNA biodiversity assessments across multiple trophic levels. Frontiers in Marine Science, 4, 314.

DOI, H., FUKAYA, K., OKA, S.-I., SATO, K., KONDOH, M. \& MIYA, M. 2019. Evaluation of detection probabilities at the water-filtering and initial PCR steps in environmental DNA metabarcoding using a multispecies site occupancy model. Scientific reports, 9, 3581.

DUNN, D. C., MAXWELL, S. M., BOUSTANY, A. M. \& HALPIN, P. N. 2016. Dynamic ocean management increases the efficiency and efficacy of fisheries management. Proceedings of the National Academy of Sciences, 113, 668-673.

ECKERT, I. M., LITTLEFAIR, J. E., ZHANG, G. K., CHAIN, F. J., CREASE, T. J. \& CRISTESCU, M. E. 2018. Bioinformatics for Biomonitoring: Species Detection and Diversity Estimates Across NextGeneration Sequencing Platforms. NEXT GENERATION BIOMONITORING, PT 2, 59, 1-32.

EDGAR, G. J., STUART-SMITH, R. D., WILLIS, T. J., KININMONTH, S., BAKER, S. C., BANKS, S., BARRETT, N. S., BECERRO, M. A., BERNARD, A. T. F., BERKHOUT, J., BUXTON, C. D., CAMPBELL, S. J., COOPER, A. T., DAVEY, M., EDGAR, S. C., FORSTERRA, G., GALVAN, D. E., IRIGOYEN, A. J., KUSHNER, D. J., MOURA, R., PARNELL, P. E., SHEARS, N. T., SOLER, G., STRAIN, E. M. A. \& THOMSON, R. J. 2014. Global conservation outcomes depend on marine protected areas with five key features. Nature, 506, 216-+.

EILERS, K. G., DEBENPORT, S., ANDERSON, S. \& FIERER, N. 2012. Digging deeper to find unique microbial communities: the strong effect of depth on the structure of bacterial and archaeal communities in soil. Soil Biology and Biochemistry, 50, 58-65.

ELITH, J. \& LEATHWICK, J. 2009. The contribution of species distribution modelling to conservation prioritization. Spatial conservation prioritization: quantitative methods, 70-93.

EVANS, D. M., KITSON, J. J., LUNT, D. H., STRAW, N. A. \& POCOCK, M. J. 2016. Merging DNA metabarcoding and ecological network analysis to understand and build resilient terrestrial ecosystems. Functional ecology, 30, 1904-1916.

EVANS, N. T., LI, Y., RENSHAW, M. A., OLDS, B. P., DEINER, K., TURNER, C. R., JERDE, C. L., LODGE, D. M., LAMBERTI, G. A. \& PFRENDER, M. E. 2017. Fish community assessment with eDNA metabarcoding: effects of sampling design and bioinformatic filtering. Canadian Journal of Fisheries and Aquatic Sciences, 74, 1362-1374.

FERNANDES, L., DAY, J., LEWIS, A., SLEGERS, S., KERRIGAN, B., BREEN, D., CAMERON, D., JAGO, B., HALL, J., LOWE, D., INNES, J., TANZER, J., CHADWICK, V., THOMPSON, L., GORMAN, K., SIMMONS, M., BARNETT, B., SAMPSON, K., DE'ATH, G., MAPSTONE, B., MARSH, H., POSSINGHAM, H., BALL, I., WARD, T., DOBBS, K., AUMEND, J., SLATER, D. \& STAPLETON, K. 2005. Establishing representative no-take areas in the Great Barrier Reef: Large-scale implementation of theory on marine protected areas. Conservation Biology, 19, 1733-1744. 
FICETOLA, G. F., PANSU, J., BONIN, A., COISSAC, E., GIGUET-COVEX, C., DE BARBA, M., GIELLY, L., LOPES, C. M., BOYER, F. \& POMPANON, F. 2015. Replication levels, false presences and the estimation of the presence/absence from eDNA metabarcoding data. Molecular ecology resources, 15, 543-556.

FICETOLA, G. F., TABERLET, P. \& COISSAC, E. 2016. How to limit false positives in environmental DNA and metabarcoding? Molecular ecology resources, 16, 604-607.

FICETOLA, G. F., THUILLER, W. \& MIAUD, C. 2007. Prediction and validation of the potential global distribution of a problematic alien invasive species-the American bullfrog. Diversity and distributions, 13, 476-485.

GAME, E. T., MEIJAARD, E., SHEIL, D. \& MCDONALD-MADDEN, E. 2014. Conservation in a wicked complex world; challenges and solutions. Conservation Letters, 7, 271-277.

GILBERT, J. A., JANSSON, J. K. \& KNIGHT, R. 2014. The Earth Microbiome project: successes and aspirations. BMC biology, 12, 69.

GRANTHAM, H. S., AGOSTINI, V. N., WILSON, J., MANGUBHAI, S., HIDAYAT, N., MULJADI, A., MUHAJIR, ROTINSULU, C., MONGDONG, M., BECK, M. W. \& POSSINGHAM, H. P. 2013. A comparison of zoning analyses to inform the planning of a marine protected area network in Raja Ampat, Indonesia. Marine Policy, 38, 184-194.

GREEN, A., SMITH, S. E., LIPSETT-MOORE, G., GROVES, C., PETERSON, N., SHEPPARD, S., LOKANI, P., HAMILTON, R., ALMANY, J., AITSI, J. \& BUALIA, L. 2009. Designing a resilient network of marine protected areas for Kimbe Bay, Papua New Guinea. Oryx, 43, 1-11.

GUISAN, A., TINGLEY, R., BAUMGARTNER, J. B., NAUJOKAITIS-LEWIS, I., SUTCLIFFE, P. R., TULLOCH, A. I., REGAN, T. J., BROTONS, L., MCDONALD-MADDEN, E. \& MANTYKA-PRINGLE, C. 2013. Predicting species distributions for conservation decisions. Ecology letters, 16, 1424-1435.

HOBDAY, A. J., HARTOG, J. R., SPILLMAN, C. M. \& ALVES, O. 2011. Seasonal forecasting of tuna habitat for dynamic spatial management. Canadian Journal of Fisheries and Aquatic Sciences, 68, 898911.

HOLMAN, L. E., DE BRUYN, M., CREER, S., CARVALHO, G., ROBIDART, J. \& RIUS, M. 2019. Detection of introduced and resident marine species using environmental DNA metabarcoding of sediment and water. Scientific reports, 9, 1-10.

HUGHES, T. P., BARNES, M. L., BELLWOOD, D. R., CINNER, J. E., CUMMING, G. S., JACKSON, J. B. C., KLEYPAS, J., VAN DE LEEMPUT, I. A., LOUGH, J. M., MORRISON, T. H., PALUMBI, S. R., VAN NES, E. H. \& SCHEFFER, M. 2017. Coral reefs in the Anthropocene. Nature, 546, 82-90.

HUNTER, M. E., OYLER-MCCANCE, S. J., DORAZIO, R. M., FIKE, J. A., SMITH, B. J., HUNTER, C. T., REED, R. N. \& HART, K. M. 2015. Environmental DNA (eDNA) sampling improves occurrence and detection estimates of invasive Burmese pythons. PloS one, 10, e0121655.

IACONA, G., RAMACHANDRA, A., MCGOWAN, J., DAVIES, A., JOPPA, L., KOH, L. P., FEGRAUS, E., GAME, E., GUILLERA-ARROITA, G. \& HARCOURT, R. 2019. Identifying technology solutions to bring conservation into the innovation era. Frontiers in Ecology and the Environment.

IKEDA, K., DOI, H., TANAKA, K., KAWAI, T. \& NEGISHI, J. N. 2016. Using environmental DNA to detect an endangered crayfish Cambaroides japonicus in streams. Conservation Genetics Resources, 8, 231-234.

ISHIGE, T., MIYA, M., USHIO, M., SADO, T., USHIODA, M., MAEBASHI, K., YONECHI, R., LAGAN, P. \& MATSUBAYASHI, H. 2017. Tropical-forest mammals as detected by environmental DNA at natural saltlicks in Borneo. Biological conservation, 210, 281-285.

JANE, S. F., WILCOX, T. M., MCKELVEY, K. S., YOUNG, M. K., SCHWARTZ, M. K., LOWE, W. H., LETCHER, B. H. \& WHITELEY, A. R. 2015. Distance, flow and PCR inhibition: e DNA dynamics in two headwater streams. Molecular ecology resources, 15, 216-227.

JERDE, C. L., OLDS, B. P., SHOGREN, A. J., ANDRUSZKIEWICZ, E. A., MAHON, A. R., BOLSTER, D. \& TANK, J. L. 2016. Influence of stream bottom substrate on retention and transport of vertebrate environmental DNA. Environmental science \& technology, 50, 8770-8779. 
JERDE, C. L., WILSON, E. A. \& DRESSLER, T. L. 2019. Measuring global fish species richness with eDNA metabarcoding. Molecular Ecology Resources, 19, 19-22.

JEUNEN, G. J., KNAPP, M., SPENCER, H. G., LAMARE, M. D., TAYLOR, H. R., STAT, M., BUNCE, M. \& GEMMELL, N. J. 2019. Environmental DNA (eDNA) metabarcoding reveals strong discrimination among diverse marine habitats connected by water movement. Molecular ecology resources, 19, 426-438.

JO, H., VENTURA, M., VIDAL, N., GIM, J. S., BUCHACA, T., BARMUTA, L. A., JEPPESEN, E. \& JOO, G. J. 2016. Discovering hidden biodiversity: the use of complementary monitoring of fish diet based on DNA barcoding in freshwater ecosystems. Ecology and evolution, 6, 219-232.

JO, T., MURAKAMI, H., MASUDA, R., SAKATA, M. K., YAMAMOTO, S. \& MINAMOTO, T. 2017. Rapid degradation of longer DNA fragments enables the improved estimation of distribution and biomass using environmental DNA. Molecular ecology resources, 17, e25-e33.

JO, T., MURAKAMI, H., YAMAMOTO, S., MASUDA, R. \& MINAMOTO, T. 2019. Effect of water temperature and fish biomass on environmental DNA shedding, degradation, and size distribution. Ecology and evolution, 9, 1135-1146.

JULIAN, J. T., GLENNEY, G. W. \& REES, C. 2019. Evaluating observer bias and seasonal detection rates in amphibian pathogen eDNA collections by citizen scientists. Diseases of Aquatic Organisms, $134,15-24$.

KAMOROFF, C. \& GOLDBERG, C. S. 2017. Using environmental DNA for early detection of amphibian chytrid fungus Batrachochytrium dendrobatidis prior to a ranid die-off. Diseases of Aquatic Organisms, 127, 75-79.

KELLY, R. P., SHELTON, A. O. \& GALLEGO, R. 2019. Understanding pcR processes to Draw Meaningful conclusions from environmental DnA Studies. Scientific reports, 9, 1-14.

KLYMUS, K. E., MARSHALL, N. T. \& STEPIEN, C. A. 2017. Environmental DNA (eDNA) metabarcoding assays to detect invasive invertebrate species in the Great Lakes. PLoS One, 12, e0177643.

KOZIOL, A., STAT, M., SIMPSON, T., JARMAN, S., DIBATTISTA, J. D., HARVEY, E. S., MARNANE, M., MCDONALD, J. \& BUNCE, M. 2019. Environmental DNA metabarcoding studies are critically affected by substrate selection. Molecular ecology resources, 19, 366-376.

KUKKALA, A. S. \& MOILANEN, A. 2013. Core concepts of spatial prioritisation in systematic conservation planning. Biological Reviews, 88, 443-464.

LERAY, M., KNOWLTON, N., HO, S.-L., NGUYEN, B. N. \& MACHIDA, R. J. 2019. GenBank is a reliable resource for 21st century biodiversity research. Proceedings of the National Academy of Sciences, 116, 22651-22656.

LEWISON, R., HOBDAY, A. J., MAXWELL, S., HAZEN, E., HARTOG, J. R., DUNN, D. C., BRISCOE, D., FOSSETTE, S., O'KEEFE, C. E. \& BARNES, M. 2015. Dynamic ocean management: identifying the critical ingredients of dynamic approaches to ocean resource management. BioScience, 65, 486-498.

LOPES, C. M., SASSO, T., VALENTINI, A., DEJEAN, T., MARTINS, M., ZAMUDIO, K. R. \& HADDAD, C. F. 2017. eDNA metabarcoding: a promising method for anuran surveys in highly diverse tropical forests. Molecular ecology resources, 17, 904-914.

LOUCA, S., PARFREY, L. W., \& DOEBELI, M. 2016. Decoupling function and taxonomy in the global ocean microbiome. Science, 353(6305), 1272-1277.

MÄCHLER, E., OSATHANUNKUL, M. \& ALTERMATT, F. 2018. Shedding light on eDNA: neither natural levels of UV radiation nor the presence of a filter feeder affect eDNA-based detection of aquatic organisms. PLoS One, 13, e0195529.

MAGRIS, R. A., PRESSEY, R. L., WEEKS, R. \& BAN, N. C. 2014. Integrating connectivity and climate change into marine conservation planning. Biological Conservation, 170, 207-221.

MAKINO, A., KLEIN, C. J., POSSINGHAM, H. P., YAMANO, H., YARA, Y., ARIGA, T., MATSUHASI, K. \& BEGER, M. 2015. The effect of applying alternate IPCC climate scenarios to marine reserve design for range changing species. Conservation Letters, 8, 320-328. 
MAKIOLA, A., COMPSON, Z. G., BAIRD, D. J., BARNES, M. A., BOERLIJST, S. P., BOUCHEZ, A., BRENNAN, G., BUSH, A., CANARD, E., CORDIER, T., CREER, S., CURRY, R. A., DAVID, P., DUMBRELL, A. J., GRAVEL, D., HAJIBABAEI, M., HAYDEN, B., VAN DER HOORN, B., JARNE, P., JONES, J. I., KARIMI, B., KECK, F., KELLY, M., KNOT, I. E., KROL, L., MASSOL, F., MONK, W. A., MURPHY, J., PAWLOWSKI, J., POISOT, T., PORTER, T. M., RANDALL, K. C., RANSOME, E., RAVIGNÉ, V., RAYBOULD, A., ROBIN, S., SCHRAMA, M., SCHATZ, B., TAMADDONI-NEZHAD, A., TRIMBOS, K. B., VACHER, C., VASSELON, V., WOOD, S., WOODWARD, G. \& BOHAN, D. A. 2020. Key Questions for Next-Generation Biomonitoring. Frontiers in Environmental Science, 7. MARGULES, C. R. \& PRESSEY, R. L. 2000. Systematic conservation planning. Nature, 405, 243.

MARTIN, T. S. H., CONNOLLY, R. M., OLDS, A. D., CECCARELLI, D. M., FENNER, D. E., SCHLACHER, T. A. \& BEGER, M. 2017. Subsistence fishing on Pacific atolls can maintain near-pristine fish communities. ICES Journal of Marine Science, fs $\mathrm{O} 043$.

MARUYAMA, A., NAKAMURA, K., YAMANAKA, H., KONDOH, M. \& MINAMOTO, T. 2014. The release rate of environmental DNA from juvenile and adult fish. PLoS One, 9, e114639.

MAXWELL, S. L., MILNER-GULLAND, E. J., JONES, J. P. G., KNIGHT, A. T., BUNNEFELD, N., NUNO, A., BAL, P., EARLE, S., WATSON, J. E. M. \& RHODES, J. R. 2015. Being smart about SMART environmental targets. Science, 347, 1075-1076.

MCCLANAHAN, T. R. \& HICKS, C. C. 2011. Changes in life history and ecological characteristics of coral reef fish catch composition with increasing fishery management. Fisheries Management and Ecology, 18, 50-60.

MCDONALD-MADDEN, E., BAXTER, P. W., FULLER, R. A., MARTIN, T. G., GAME, E. T., MONTAMBAULT, J. \& POSSINGHAM, H. P. 2010. Monitoring does not always count. Trends in Ecology \& Evolution, 25, 547-550.

MCGEE, K. M., ROBINSON, C. \& HAJIBABAEI, M. 2019. Gaps in DNA-based Biomonitoring Across the Globe. Frontiers in Ecology and Evolution, 7, 337.

MEEKAN, M., AUSTIN, C. M., TAN, M. H., WEI, N.-W. V., MILLER, A., PIERCE, S. J., ROWAT, D., STEVENS, G., DAVIES, T. K. \& PONZO, A. 2017. iDNA at sea: recovery of whale shark (Rhincodon typus) mitochondrial DNA sequences from the whale shark copepod (Pandarus rhincodonicus) confirms global population structure. Frontiers in Marine Science, 4, 420.

MILLS, M., JUPITER, S. D., PRESSEY, R. L., BAN, N. C. \& COMLEY, J. 2011. Incorporating effectiveness of community-based management in a national marine gap analysis for Fiji. Conservation biology, 25, 1155-1164.

MORA, C., ABURTO-OROPEZA, O., AYALA BOCOS, A., AYOTTE, P. M., BANKS, S., BAUMAN, A. G., BEGER, M., BESSUDO, S., BOOTH, D. J., BROKOVICH, E., BROOKS, A., CHABANET, P., CINNER, J., CORTÉS, J., CRUZ-MOTTA, J. J., CUPUL MAGAÑA, A., DEMARTINI, E. E., EDGAR, G. J., FEARY, D. A., FERSE, S. C. A., FRIEDLANDER, A. M., GASTON, K. J., GOUGH, C., GRAHAM, N. A. J., GREEN, A., GUZMAN, H. M., HARDT, M., KULBICKI, M., LETOURNEUR, Y., LÓPEZ PÉREZ, A., LOREAU, M., LOYA, Y., MARTINEZ, C., MASCAREÑAS-OSORIO, I., MOROVE, T., NADON, M.-O., NAKAMURA, Y., PAREDES, G., POLUNIN, N. V. C., PRATCHETT, M. S., REYES BONILLA, H., RIVERA, F., SALA, E., SANDIN, S., SOLER, G., STUART-SMITH, R., TESSIER, E., TITTENSOR, D. P., TUPPER, M., USSEGLIO, P., VIGLIOLA, L., WANTIEZ, L., WILLIAMS, I. D., WILSON, S. K. \& ZAPATA, F. A. 2011. Global human footprint on the linkage between biodiversity and ecosystem functioning in reef fishes. PLoS Biology, 9, e1000606. doi:10.1371/journal.pbio.1000606.

MOUSHOMI, R., WILGAR, G., CARVALHO, G., CREER, S. \& SEYMOUR, M. 2019. Environmental DNA size sorting and degradation experiment indicates the state of Daphnia magna mitochondrial and nuclear eDNA is subcellular. Scientific reports, 9, 1-9.

NICHOLS, P. K. \& MARKO, P. B. 2019. Rapid assessment of coral cover from environmental DNA in Hawai'i. Environmental DNA.

NIELSEN, E. S., BEGER, M., HENRIQUES, R., SELKOE, K. A. \& VON DER HEYDEN, S. 2017. Multispecies genetic objectives in spatial conservation planning. Conservation biology, 31, 872-882. 
PAWLOWSKI, J., KELLY-QUINN, M., ALTERMATT, F., APOTHÉLOZ-PERRET-GENTIL, L., BEJA, P., BOGGERO, A., BORJA, A., BOUCHEZ, A., CORDIER, T. \& DOMAIZON, I. 2018. The future of biotic indices in the ecogenomic era: Integrating (e) DNA metabarcoding in biological assessment of aquatic ecosystems. Science of the Total Environment, 637, 1295-1310.

PEARMAN, J. K., LERAY, M., VILLALOBOS, R., MACHIDA, R., BERUMEN, M. L., KNOWLTON, N. \& CARVALHO, S. 2018. Cross-shelf investigation of coral reef cryptic benthic organisms reveals diversity patterns of the hidden majority. Scientific reports, 8, 8090.

PONT, D., ROCLE, M., VALENTINI, A., CIVADE, R., JEAN, P., MAIRE, A., ROSET, N., SCHABUSS, M., ZORNIG, H. \& DEJEAN, T. 2018. Environmental DNA reveals quantitative patterns of fish biodiversity in large rivers despite its downstream transportation. Scientific reports, 8, 10361.

PORTER, T. M. \& HAJIBABAEI, M. 2018a. Over 2.5 million COI sequences in GenBank and growing. PloS one, 13, e0200177.

PORTER, T. M. \& HAJIBABAEI, M. 2018b. Scaling up: A guide to high-throughput genomic approaches for biodiversity analysis. Molecular ecology, 27, 313-338.

REES, H. C., MADDISON, B. C., MIDDLEDITCH, D. J., PATMORE, J. R. \& GOUGH, K. C. 2014. The detection of aquatic animal species using environmental DNA-a review of eDNA as a survey tool in ecology. Journal of Applied Ecology, 51, 1450-1459.

ROBINSON, C. V., GARCIA DE LEANIZ, C., ROLLA, M. \& CONSUEGRA, S. 2019. Monitoring the eradication of the highly invasive topmouth gudgeon (Pseudorasbora parva) using a novel eDNA assay. Environmental DNA, 1, 74-85.

ROBSON, H. L., NOBLE, T. H., SAUNDERS, R. J., ROBSON, S. K., BURROWS, D. W. \& JERRY, D. R. 2016. Fine-tuning for the tropics: application of eDNA technology for invasive fish detection in tropical freshwater ecosystems. Molecular ecology resources, 16, 922-932.

RUPPERT, K. M., KLINE, R. J. \& RAHMAN, M. S. 2019. Past, present, and future perspectives of environmental DNA (eDNA) metabarcoding: A systematic review in methods, monitoring, and applications of global eDNA. Global Ecology and Conservation, e00547.

RUSS, G. R., MILLER, K. I., RIZZARI, J. R. \& ALCALA, A. C. 2015. Long-term no-take marine reserve and benthic habitat effects on coral reef fishes. Marine Ecology Progress Series, 529, 233-248.

SALES, N. G., WANGENSTEEN, O. S., CARVALHO, D. C. \& MARIANI, S. 2019. Influence of preservation methods, sample medium and sampling time on eDNA recovery in a neotropical river. Environmental DNA.

SASSOUBRE, L. M., YAMAHARA, K. M., GARDNER, L. D., BLOCK, B. A. \& BOEHM, A. B. 2016. Quantification of environmental DNA (eDNA) shedding and decay rates for three marine fish. Environmental science \& technology, 50, 10456-10464.

SHAW, J. L., WEYRICH, L. \& COOPER, A. 2017. Using environmental (e) DNA sequencing for aquatic biodiversity surveys: a beginner's guide. Marine and Freshwater Research, 68, 20-33.

SHOGREN, A. J., TANK, J. L., ANDRUSZKIEWICZ, E., OLDS, B., MAHON, A. R., JERDE, C. L. \& BOLSTER, D. 2017. Controls on eDNA movement in streams: Transport, retention, and resuspension. Scientific Reports, 7, 5065.

SIGSGAARD, E. E., CARL, H., M ØLLER, P. R. \& THOMSEN, P. F. 2015. Monitoring the near-extinct European weather loach in Denmark based on environmental DNA from water samples. Biological Conservation, 183, 46-52.

SIGSGAARD, E. E., NIELSEN, I. B., BACH, S. S., LORENZEN, E. D., ROBINSON, D. P., KNUDSEN, S. W., PEDERSEN, M. W., AL JAIDAH, M., ORLANDO, L. \& WILLERSLEV, E. 2017a. Population characteristics of a large whale shark aggregation inferred from seawater environmental DNA. Nature ecology \& evolution, 1, 0004.

SIGSGAARD, E. E., NIELSEN, I. B., CARL, H., KRAG, M. A., KNUDSEN, S. W., XING, Y., HOLM-HANSEN, T. H., MØLLER, P. R. \& THOMSEN, P. F. 2017b. Seawater environmental DNA reflects seasonality of a coastal fish community. Marine Biology, 164, 128. 
SIMPFENDORFER, C. A., KYNE, P. M., NOBLE, T. H., GOLDSBURY, J., BASIITA, R. K., LINDSAY, R., SHIELDS, A., PERRY, C. \& JERRY, D. R. 2016. Environmental DNA detects Critically Endangered largetooth sawfish in the wild. Endangered Species Research, 30, 109-116.

SØNSTEB $\varnothing$, J., GIELLY, L., BRYSTING, A., ELVEN, R., EDWARDS, M., HAILE, J., WILLERSLEV, E., COISSAC, E., RIOUX, D. \& SANNIER, J. 2010. Using next-generation sequencing for molecular reconstruction of past Arctic vegetation and climate. Molecular ecology resources, 10, 10091018.

STAT, M., HUGGETT, M. J., BERNASCONI, R., DIBATTISTA, J. D., BERRY, T. E., NEWMAN, S. J., HARVEY, E. S. \& BUNCE, M. 2017. Ecosystem biomonitoring with eDNA: metabarcoding across the tree of life in a tropical marine environment. Scientific Reports, 7, 12240.

STAT, M., JOHN, J., DIBATTISTA, J. D., NEWMAN, S. J., BUNCE, M. \& HARVEY, E. S. 2019. Combined use of eDNA metabarcoding and video surveillance for the assessment of fish biodiversity. Conservation biology, 33, 196-205.

STEWART, K., MA, H., ZHENG, J. \& ZHAO, J. 2017. Using environmental DNA to assess population-wide spatiotemporal reserve use. Conservation Biology, 31, 1173-1182.

STEWART, J., HEGARTY, A. M., YOUNG, C., \& FOWLER, A. M. 2018. Sex-specific differences in growth, mortality and migration support population resilience in the heavily exploited migratory marine teleost Mugil cephalus (Linnaeus 1758). Marine and Freshwater Research, 69(3), 385394.

STRICKLAND, G. J. \& ROBERTS, J. H. 2019. Utility of eDNA and occupancy models for monitoring an endangered fish across diverse riverine habitats. Hydrobiologia, 826, 129-144.

SUTHERLAND, W., ADAMS, W., ARONSON, R., AVELING, R., BLACKBURN, T., BROAD, S., CEBALLOS, G., COTE, I., COWLING, R. \& DA FONSECA, G. 2009. One hundred questions of importance to the conservation of global biological diversity. Conservation Biology, 23, 557-567.

SUTHERLAND, W. J., BUTCHART, S. H., CONNOR, B., CULSHAW, C., DICKS, L. V., DINSDALE, J., DORAN, H., ENTWISTLE, A. C., FLEISHMAN, E. \& GIBBONS, D. W. 2018. A 2018 horizon scan of emerging issues for global conservation and biological diversity. Trends in ecology \& evolution, 33, 4758.

TAKAHARA, T., MINAMOTO, T., YAMANAKA, H., DOI, H. \& KAWABATA, Z. I. 2012. Estimation of fish biomass using environmental DNA. PloS one, 7, e35868.

THOMPSON, M. S., BANKIER, C., BELL, T., DUMBRELL, A. J., GRAY, C., LEDGER, M. E., LEHMANN, K., MCKEW, B. A., SAYER, C. D. \& SHELLEY, F. 2016. Gene-to-ecosystem impacts of a catastrophic pesticide spill: testing a multilevel bioassessment approach in a river ecosystem. Freshwater Biology, 61, 2037-2050.

THOMSEN, P. F. \& WILLERSLEV, E. 2015. Environmental DNA-An emerging tool in conservation for monitoring past and present biodiversity. Biological conservation, 183, 4-18.

TITTENSOR, D. P., BEGER, M., BOERDER, K., BOYCE, D. G., CAVANAGH, R. D., COSANDEY-GODIN, A., CRESPO, G. O., DUNN, D. C., GHIFFARY, W., GRANT, S. M., HANNAH, L., HALPIN, P. N., HARFOOT, M., HEASLIP, S. G., JEFFERY, N. W., KINGSTON, N., LOTZE, H. K., MCGOWAN, J., MCLEOD, E., MCOWEN, C. J., O'LEARY, B. C., SCHILLER, L., STANLEY, R. R. E., WESTHEAD, M., WILSON, K. L. \& WORM, B. 2019. Integrating climate adaptation and biodiversity conservation in the global ocean. Science Advances, 5, eaay9969.

TULLOCH, A. I., CHADÈS, I. \& LINDENMAYER, D. B. 2018. Species co-occurrence analysis predicts management outcomes for multiple threats. Nature ecology \& evolution, 2, 465.

UNSWORTH, R. K. F., JONES, B. L. \& CULLEN-UNSWORTH, L. C. 2016. Seagrass meadows are threatened by expected loss of peatlands in Indonesia. Global Change Biology, 22, 2957-2958.

UTHICKE, S., LAMARE, M. \& DOYLE, J. R. 2018. eDNA detection of corallivorous seastar (Acanthaster cf. solaris) outbreaks on the Great Barrier Reef using digital droplet PCR. Coral Reefs, 37, 12291239. 
VALDEZ-MORENO, M., IVANOVA, N. V., ElIAS-GUTIERREZ, M., PEDERSEN, S. L., BESSONOV, K. \& HEBERT, P. D. 2019. Using eDNA to biomonitor the fish community in a tropical oligotrophic lake. PloS one, 14, e0215505.

VAN DIJK, E. L., JASZCZYSZYN, Y., NAQUIN, D. \& THERMES, C. 2018. The third revolution in sequencing technology. Trends in Genetics, 34, 666-681.

VERCAMMEN, A., MCGOWAN, J. A., KNIGHT, A. T., PARDEDE, S., MUTTAQIN, E., HARRIS, J., AHMADIA, G. N., ESTRADIVARI, DALLISON, T., SELIG, E. R. \& BEGER, M. 2019. Evaluating the impact of accounting for coral cover in large-scale marine conservation prioritisations. Diversity and Distributions, https://doi.org/10.1111/ddi.12957.

VIMAL, R., RODRIGUES, A. S., MATHEVET, R. \& THOMPSON, J. D. 2011. The sensitivity of gap analysis to conservation targets. Biodiversity and conservation, 20, 531-543.

VON DER HEYDEN, S., BEGER, M., TOONEN, R. J., VAN HERWERDEN, L., JUINIO-MEÑEZ, M. A., RAVAGOGOTANCO, R., FAUVELOT, C. \& BERNARDI, G. 2014. The application of genetics to marine management and conservation: examples from the Indo-Pacific. Bulletin of Marine Science, 90, 123-158.

WALKER, D. M., LEYS, J. E., DUNHAM, K. E., OLIVER, J. C., SCHILLER, E. E., STEPHENSON, K. S., KIMREY, J. T., WOOTEN, J. \& ROGERS, M. W. 2017. Methodological considerations for detection of terrestrial small-body salamander eDNA and implications for biodiversity conservation. Molecular ecology resources, 17, 1223-1230.

WEEKS, R., ALINO, P. M., ATKINSON, S., BELDIA, P., BINSON, A., CAMPOS, W. L., DJOHANI, R., GREEN, A. L., HAMILTON, R., HORIGUE, V., JUMIN, R., KALIM, K., KASASIAH, A., KERESEKA, J., KLEIN, C., LAROYA, L., MAGUPIN, S., MASIKE, B., MOHAN, C., PINTO, R. M. D., VAVE-KARAMUI, A., VILLANOY, C., WELLY, M. \& WHITE, A. T. 2014. Developing marine protected area networks in the Coral Triangle: good practices for expanding the Coral Triangle Marine Protected Area System. Coastal Management, 42, 183-205.

WEI, N., NAKAJIMA, F. \& TOBINO, T. 2018. A microcosm study of surface sediment environmental DNA: decay observation, abundance estimation, and fragment length comparison. Environmental science \& technology, 52, 12428-12435.

WELTZ, K., LYLE, J. M., OVENDEN, J., MORGAN, J. A., MORENO, D. A. \& SEMMENS, J. M. 2017. Application of environmental DNA to detect an endangered marine skate species in the wild. PloS one, 12, e0178124.

WILLERSLEV, E., DAVISON, J., MOORA, M., ZOBEL, M., COISSAC, E., EDWARDS, M. E., LORENZEN, E. D., VESTERGÅRD, M., GUSSAROVA, G. \& HAILE, J. 2014. Fifty thousand years of Arctic vegetation and megafaunal diet. Nature, 506, 47.

WILLIAMS, B. K. \& BROWN, E. D. 2016. Technical challenges in the application of adaptive management. Biological Conservation, 195, 255-263.

WILSON, K. A., CARWARDINE, J. \& POSSINGHAM, H. P. 2009. Setting conservation priorities. Annals of the New York Academy of Sciences, 1162, 237-264.

WILSON, K. A., UNDERWOOD, E. C., MORRISON, S. A., KLAUSMEYER, K. R., MURDOCH, W. W., REYERS, B., WARDELL-JOHNSON, G., MARQUET, P. A., RUNDEL, P. W., MCBRIDE, M. F., PRESSEY, R. L., BODE, M., HOEKSTRA, J. M., ANDELMAN, S., LOOKER, M., RONDININI, C., KAREIVA, P., SHAW, M. R. \& POSSINGHAM, H. P. 2007. Conserving biodiversity efficiently: what to do, where, and when. PLoS Biology, 5, e223.

WU, D., STRUWE, W. B., HARVEY, D. J., FERGUSON, M. A. J. \& ROBINSON, C. V. 2018. N-glycan microheterogeneity regulates interactions of plasma proteins. Proceedings of the National Academy of Sciences of the United States of America, 115, 8763-8768.

ZINGER, L., BONIN, A., ALSOS, I. G., BÁLINT, M., BIK, H., BOYER, F., CHARITON, A. A., CREER, S., COISSAC, E. \& DEAGLE, B. E. 2019. DNA metabarcoding-Need for robust experimental designs to draw sound ecological conclusions. Molecular ecology, 28, 1857-1862. 
Table 1. Potential spatial planning objectives used in spatial planning and how the use of eDNA

could influence future practice for tropical marine systems, references provided where available.

\begin{tabular}{|c|c|c|c|c|c|}
\hline $\begin{array}{l}\text { Conservation } \\
\text { objective }\end{array}$ & $\begin{array}{l}\text { Conservat } \\
\text { ion action }\end{array}$ & Data needed & $\begin{array}{l}\text { Current } \\
\text { challenges }\end{array}$ & $\begin{array}{l}\text { eDNA } \\
\text { opportunities }\end{array}$ & $\begin{array}{l}\text { Examples of } \\
\text { eDNA use }\end{array}$ \\
\hline $\begin{array}{l}\text { Identify and } \\
\text { eradicate invasive } \\
\text { species }\end{array}$ & $\begin{array}{l}\text { Robinson et } \\
\text { al. (2019) }\end{array}$ & $\begin{array}{l}\text { Presence/ } \\
\text { absence of } \\
\text { invasive } \\
\text { species }\end{array}$ & $\begin{array}{l}\text { Low } \\
\text { detection } \\
\text { probability }\end{array}$ & $\begin{array}{l}\text { Increased } \\
\text { detection } \\
\text { probability }+ \\
\text { decreased cost }\end{array}$ & $\begin{array}{l}\text { Holman et al. } \\
(2019)\end{array}$ \\
\hline $\begin{array}{l}\text { Manage rare/ } \\
\text { threatened species }\end{array}$ & $\begin{array}{l}\text { Stewart et } \\
\text { al. }(2017)\end{array}$ & $\begin{array}{l}\text { Presence/ } \\
\text { absence of } \\
\text { species }\end{array}$ & $\begin{array}{l}\text { Low } \\
\text { detection } \\
\text { probability }\end{array}$ & $\begin{array}{l}\text { Increased } \\
\text { detection } \\
\text { probability }+ \\
\text { decreased cost }\end{array}$ & $\begin{array}{l}\text { Stewart et al. } \\
(2017)\end{array}$ \\
\hline $\begin{array}{l}\text { Represent cryptic } \\
\text { species }\end{array}$ & $\begin{array}{l}\text { DiBattista } \\
\text { et al. (2017) }\end{array}$ & $\begin{array}{l}\text { Cryptic } \\
\text { species } \\
\text { detection }\end{array}$ & $\begin{array}{l}\text { Low } \\
\text { detection } \\
\text { probability }\end{array}$ & $\begin{array}{l}\text { Increased } \\
\text { detection } \\
\text { probability }+ \\
\text { decreased cost }\end{array}$ & $\begin{array}{l}\text { Holman et al. } \\
(2019)\end{array}$ \\
\hline $\begin{array}{l}\text { Baseline biodiversity } \\
\text { assessment }\end{array}$ & $\begin{array}{l}\text { Stat et al. } \\
(2017)\end{array}$ & $\begin{array}{l}\text { Species } \\
\text { presence data } \\
\text { from entire } \\
\text { assemblage }\end{array}$ & $\begin{array}{l}\text { Expensive to } \\
\text { collect fully } \\
\text { representativ } \\
\text { e samples }\end{array}$ & $\begin{array}{l}\text { Can be collected } \\
\text { in single sample }\end{array}$ & $\begin{array}{l}\text { Stat et al } 2017 \\
\text { Cilleros et al } \\
2019\end{array}$ \\
\hline $\begin{array}{l}\text { Protect ecosystem } \\
\text { functions of poorly } \\
\text { studied taxa }\end{array}$ & $\begin{array}{l}\text { Costello et } \\
\text { al } 2015\end{array}$ & $\begin{array}{l}\text { Little known } \\
\text { taxa }\end{array}$ & $\begin{array}{l}\text { High } \\
\text { taxonomic } \\
\text { expertise } \\
\text { required }\end{array}$ & $\begin{array}{l}\text { Reference } \\
\text { database return } \\
\text { species / OTUs } \\
\text { for most taxa }\end{array}$ & $\begin{array}{l}\text { Not available } \\
\text { yet }\end{array}$ \\
\hline $\begin{array}{l}\text { Manage ecological } \\
\text { networks }\end{array}$ & $\begin{array}{l}\text { Tulloch et } \\
\text { al. } 2018\end{array}$ & $\begin{array}{l}\text { Species } \\
\text { abundance } \\
\text { data from } \\
\text { entire } \\
\text { assemblage }\end{array}$ & $\begin{array}{l}\text { Intensive } \\
\text { data } \\
\text { collection }+ \\
\text { unlikely to } \\
\text { cover entire } \\
\text { assemblage }\end{array}$ & $\begin{array}{l}\text { Full assemblage } \\
\text { collected }+ \\
\text { reduced } \\
\text { sampling effort }\end{array}$ & $\begin{array}{l}\text { Not available } \\
\text { yet }\end{array}$ \\
\hline $\begin{array}{l}\text { Manage trophic } \\
\text { functioning }\end{array}$ & $\begin{array}{l}\text { Mills et al. } \\
\text { (2011) }\end{array}$ & $\begin{array}{l}\text { Invertebrate } \\
\text { data }\end{array}$ & $\begin{array}{l}\text { Low } \\
\text { detection } \\
\text { probability }+ \\
\text { intensive } \\
\text { data } \\
\text { collection }\end{array}$ & $\begin{array}{l}\text { Increased } \\
\text { detection } \\
\text { probability }+ \\
\text { Tree of Life } \\
\text { assemblage } \\
\text { collection } \\
\text { possible }\end{array}$ & $\begin{array}{l}\text { Not available } \\
\text { yet }\end{array}$ \\
\hline
\end{tabular}




\begin{tabular}{|c|c|c|c|c|c|}
\hline $\begin{array}{l}\text { Protect ecosystem } \\
\text { functions of } \\
\text { microorganism (e.g. } \\
\text { macronutrient } \\
\text { cycling) }\end{array}$ & $\begin{array}{l}\text { Louca et al. } \\
2016\end{array}$ & $\begin{array}{l}\text { Microbial } \\
\text { functional } \\
\text { gene }\end{array}$ & $\begin{array}{l}\text { Target } \\
\text { studies on } \\
\text { specific gene }\end{array}$ & $\begin{array}{l}\text { Single sample } \\
\text { can provide } \\
\text { information on } \\
\text { microbial } \\
\text { functionality as } \\
\text { well as baseline } \\
\text { biodiversity data }\end{array}$ & $\begin{array}{l}\text { Delmont et al. } \\
\text { (2018) }\end{array}$ \\
\hline $\begin{array}{l}\text { Find priority areas } \\
\text { for connected } \\
\text { protected area } \\
\text { networks }\end{array}$ & $\begin{array}{l}\text { Beger et al. } \\
(2014), \\
\text { Nielsen et } \\
\text { al. (2017) }\end{array}$ & $\begin{array}{l}\text { Population } \\
\text { genetics of } \\
\text { target species }\end{array}$ & $\begin{array}{l}\text { Invasive + } \\
\text { intensive } \\
\text { sampling } \\
\text { effort }\end{array}$ & $\begin{array}{l}\text { Non-invasive + } \\
\text { reduced } \\
\text { sampling effort }\end{array}$ & $\begin{array}{l}\text { Sigsgaard et al. } \\
(2017 a)\end{array}$ \\
\hline $\begin{array}{l}\text { Avoid protecting } \\
\text { exclusion areas }\end{array}$ & $\begin{array}{l}\text { Daigle et al. } \\
\text { (2018) }\end{array}$ & $\begin{array}{l}\text { In-depth } \\
\text { knowledge of } \\
\text { ecosystem } \\
\text { function + } \\
\text { presence/ } \\
\text { absence data } \\
\text { target species }\end{array}$ & $\begin{array}{l}\text { Not possible } \\
\text { or not cost- } \\
\text { effective }\end{array}$ & $\begin{array}{l}\text { Increased } \\
\text { detection } \\
\text { probability }+ \\
\text { decreased cost }\end{array}$ & $\begin{array}{l}\text { Not available } \\
\text { yet }\end{array}$ \\
\hline $\begin{array}{l}\text { Monitoring: Assess } \\
\text { trends in species } \\
\text { populations }\end{array}$ & $\begin{array}{l}\text { McDonald- } \\
\text { Madden et } \\
\text { al. (2010) }\end{array}$ & $\begin{array}{l}\text { Abundance } \\
\text { data }\end{array}$ & $\begin{array}{l}\text { Low } \\
\text { detection } \\
\text { probability }+ \\
\text { labour } \\
\text { intensive to } \\
\text { get accurate } \\
\text { abundance of } \\
\text { target species }\end{array}$ & $\begin{array}{l}\text { Not deployed } \\
\text { yet, easier to } \\
\text { standardise } \\
\text { through time }\end{array}$ & $\begin{array}{l}\text { Bista et al. } \\
\text { (2017), } \\
\text { Sigsgaard et al. } \\
(2017 b)\end{array}$ \\
\hline $\begin{array}{l}\text { Monitoring: Assess } \\
\text { sex and/ or age of } \\
\text { populations }\end{array}$ & $\begin{array}{l}\text { Stewart et } \\
\text { al. } 2018\end{array}$ & $\begin{array}{l}\text { In-depth } \\
\text { knowledge of } \\
\text { the species }\end{array}$ & $\begin{array}{l}\text { Invasive + } \\
\text { intensive } \\
\text { sampling } \\
\text { effort }\end{array}$ & $\begin{array}{l}\text { Not deployed } \\
\text { yet }\end{array}$ & $\begin{array}{l}\text { Not available } \\
\text { yet }\end{array}$ \\
\hline $\begin{array}{l}\text { Monitoring: } \\
\text { Maintain large scale } \\
\text { (global) sampling of } \\
\text { population trends }\end{array}$ & $\begin{array}{l}\text { Thompson } \\
\text { et al. (2016) }\end{array}$ & $\begin{array}{l}\text { Biodiversity } \\
\text { data large } \\
\text { geographic } \\
\text { scale }\end{array}$ & $\begin{array}{l}\text { Extensive, } \\
\text { standardised } \\
\text { sampling } \\
\text { effort }+ \\
\text { expensive }\end{array}$ & $\begin{array}{l}\text { Decreased } \\
\text { sampling cost }+ \\
\text { easier to } \\
\text { standardise }\end{array}$ & $\begin{array}{l}\text { Gilbert et al. } \\
(2014)\end{array}$ \\
\hline
\end{tabular}


planning, references provided where available.

\begin{tabular}{|c|c|c|c|}
\hline Factor & Challenge & Future & (Review) References \\
\hline $\begin{array}{l}\text { Abiotic and } \\
\text { biotic } \\
\text { degradation }\end{array}$ & $\begin{array}{l}\text { Very limited information on } \\
\text { tropical environments } \\
\text { (e.g. Temperature, pH, UV } \\
\text { intensity) }\end{array}$ & $\begin{array}{l}\text { Quantify decay rate-biophysical } \\
\text { conditions relationships for } \\
\text { different settings }\end{array}$ & $\begin{array}{l}\text { Lopes et al. (2017), Sales et } \\
\text { al. (2019), Valdez-Moreno } \\
\text { et al. (2019) }\end{array}$ \\
\hline \multirow[t]{3}{*}{$\begin{array}{l}\text { Sampling and } \\
\text { analysis method } \\
\text { efficiency }\end{array}$} & $\begin{array}{l}\text { Differences in sampling } \\
\text { method (substrate, volume, } \\
\text { extraction, primers) influence } \\
\text { results. }\end{array}$ & $\begin{array}{l}\text { Quantify differences associated } \\
\text { with different sampling methods }\end{array}$ & $\begin{array}{l}\text { McGee et al. (2019), } \\
\text { Holman et al. (2019) }\end{array}$ \\
\hline & $\begin{array}{l}\text { Sample size and replication } \\
\text { varies across studies }\end{array}$ & $\begin{array}{l}\text { Develop hierarchical standardised } \\
\text { protocols for multi-purpose eDNA } \\
\text { analyses. }\end{array}$ & $\begin{array}{l}\text { Dickie et al. (2018), } \\
\text { Mächler et al. (2018), Rees } \\
\text { et al. (2014) }\end{array}$ \\
\hline & $\begin{array}{l}\text { Use of negative controls (i.e. } \\
\text { filtration (field) and } \\
\text { extraction blank) only. }\end{array}$ & $\begin{array}{l}\text { Include positive controls (i.e. a } \\
\text { mixture of known DNA from } \\
\text { different species and at different } \\
\text { concentrations) }\end{array}$ & $\begin{array}{l}\text { Zinger et al. (2019), Evans } \\
\text { et al. (2017) }\end{array}$ \\
\hline $\begin{array}{l}\text { Bioinformatics } \\
\text { and statistical } \\
\text { analysis }\end{array}$ & $\begin{array}{l}\text { Data analysis methods are } \\
\text { variable, i.e. different } \\
\text { pipelines and algorithms }\end{array}$ & $\begin{array}{l}\text { Develop a robust bioinformatic } \\
\text { pipeline that could be used across } \\
\text { different eDNA experimental set } \\
\text { ups }\end{array}$ & $\begin{array}{l}\text { Eckert et al. (2018), Deiner } \\
\text { et al. (2017a) }\end{array}$ \\
\hline $\begin{array}{l}\text { Reference } \\
\text { databases are } \\
\text { lacking }\end{array}$ & $\begin{array}{l}\text { Lack of curated databases for } \\
\text { taxonomic assignment } \\
\text { More reference data required } \\
\text { on different markers than COI } \\
\text { Databases lack information } \\
\text { such as geographic position or } \\
\text { environmental variables }\end{array}$ & $\begin{array}{l}\text { Better population of databases } \\
\text { entries and improved curation, } \\
\text { with barcodes for identified taxa, } \\
\text { in parallel with better } \\
\text { bioinformatics algorithms } \\
\text { Development of occupancy } \\
\text { models to quantify error rates } \\
\text { (ongoing, but more depth needed) } \\
\text { Occupancy models should take in } \\
\text { account the hierarchical nature of } \\
\text { the experiment and include false } \\
\text { positives }\end{array}$ & $\begin{array}{l}\begin{array}{l}\text { Porter and Hajibabaei } \\
(2018 \mathrm{a})\end{array} \\
\text { Ficetola et al. (2015), } \\
\text { Ficetola et al. (2016) }\end{array}$ \\
\hline $\begin{array}{l}\text { Method } \\
\text { boundaries }\end{array}$ & $\begin{array}{l}\text { Turning read abundance into } \\
\text { estimated biomass }\end{array}$ & $\begin{array}{l}\text { Develop, test, and document } \\
\text { potential biomass/ abundance } \\
\text { eDNA methods }\end{array}$ & $\begin{array}{l}\text { Contradictory results } \\
\text { based on few species } \\
\text { studied } \\
\text { (Sassoubre et al., 2016, } \\
\text { Robson et al., 2016) }\end{array}$ \\
\hline
\end{tabular}




\begin{tabular}{|l|l|l|l|}
\hline $\begin{array}{l}\text { Data access and } \\
\text { compatibility }\end{array}$ & $\begin{array}{l}\text { Data storage not centralised, } \\
\text { metadata not available }\end{array}$ & $\begin{array}{l}\text { Standardised metadata recording } \\
\text { should be established and } \\
\text { metadata appropriately deposited. } \\
\text { Centralise eDNA data in open } \\
\text { access databases (with solid } \\
\text { funding) to increase use by wider } \\
\text { community }\end{array}$ & \\
\hline $\begin{array}{l}\text { Unifying spatial } \\
\text { planning with } \\
\text { eDNA data } \\
\text { framework and } \\
\text { guidelines }\end{array}$ & $\begin{array}{l}\text { Very little overlap in } \\
\text { expertise between molecular } \\
\text { ecologists and conservation } \\
\text { scientists }\end{array}$ & $\begin{array}{l}\text { Better and bigger databases that } \\
\text { could be used for spatial planning }\end{array}$ & $\begin{array}{l}\text { Neger et al. (2014), } \\
\text { der Heyden et al. (2017), von }\end{array}$ \\
\hline
\end{tabular}

Figure 1. Application of eDNA in conservation science. eDNA has been utilised in species detection (including cryptic, threatened, rare and invasive species), in diet analysis, or to survey biodiversity in complex environments. Each of these is applicable within different management contexts (Table 1).

Figure 2. Flowchart of the spatial planning process (modified from Pressey and Bottrill (2009)), with potential uses of eDNA at relevant stages. Planning: the benefits, limitations, feasibility, and cost of eDNA approaches should be carefully considered at the planning stage; Data collection: eDNA could be used to provide biodiversity baseline data; Conservation objectives: quantifiable diversity objectives could be set by using metrics generated from eDNA data; Current achievement of objectives: data collected with eDNA can be compared to objectives; Evaluation: eDNA data can be used to monitor progress on objectives.

Figure 3. Schematic guidelines for future eDNA projects that provide biodiversity data for spatial 